\title{
Modelling the intra-destination behaviour of cruise visitors based on a three-dimensional approach
}

\author{
Sandra Navarro-Ruiz ${ }^{\mathrm{a}}$ \\ Ana B. Casado-Díaz \\ Josep Ivars-Baidal $^{\mathrm{c}}$
}

${ }^{\text {a }}$ Corresponding author: Researcher in the Tourism Research Institute in the University of Alicante. Carretera San Vicente del Raspeig s/n, 03690, San Vicente del Raspeig, Spain. Email: sandra.navarro@ua.es

${ }^{\mathrm{b}}$ Department of Marketing in the University of Alicante (Spain). Carretera San Vicente del Raspeig s/n, 03690, San Vicente del Raspeig, Spain. E-mail: ana.casado@ua.es

${ }^{c}$ Department of Regional Geographic Analysis and Physical Geography in theUniversity of Alicante. Carretera San Vicente del Raspeig s/n, 03690, San Vicente del Raspeig, Spain . Email: josep.ivars@ua.es

Funding Source Declaration: Research carried out within the project "Analysis of planning processes applied to smart cities and smart tourism destinations. Balance and methodological proposal for tourist spaces: Smart Tourism Planning" (CSO2017-82592-R) under the Spanish National R\&D\&I Plan funded by the Ministry of Economy, Industry and Competitiveness / [UAFPU2016-014]

Please, cite as:

Navarro-Ruiz, S., Casado-Díaz, A. B., \& Ivars-Baidal, J. (2020). Modelling the intra-destination behaviour of cruise visitors based on a three-dimensional approach. Journal of Destination Marketing \& Management, 18, 100470.

https://doi.org/10.1016/j.jdmm.2020.100470 


\section{Modelling the intra-destination behaviour of cruise visitors based on a three-dimensional approach}

Intra-destination behaviour of cruise visitors expands the spatial behaviour framework by adopting a holistic perspective that includes spatial movement, time consumption, and participation patterns with attractions. A multi-method approach was employed in order to collect and triangulate different data obtained through questionnaires, trip diaries and GPS tracking technologies. Specifically, this research was conducted in the city of Valencia using a sample of 503 cruise visitors, a consolidated urban destination and an emergent Mediterranean cruise port of call. The findings revealed five intra-destination behaviour patterns based on the number of tourist nodes visited (single or multiple) and the activities carried out (active or passive). Cruise visitors who stayed in a single node tended to perform passive activities (panoramic and contemplative visits), while cruise visitors who visited multiple nodes prefered to combine immersive/active activities and contemplative ones within the nodes. Furthermore, interesting differences between the profiles of the different groups were highlighted. These findings have a practical significance for destination managers in order to prevent potential negative impacts. Likewise, the three-dimensional approach proposed that arises from the visitor-destination-attraction relationship and the empirical design can enhance future research on the topic.

Keywords: Intra-destination behaviour, Time-space, Participation patterns, Tourist activity, Cruise tourism, Multi-method approach, Spatial analysis

\section{Introduction}

The intra-destination mobility framework needs to be updated to include not only the spatial and temporal dimensions, but also the visitor's experience within a destination. This approach would increase the current knowledge about how visitors consume a destination, thereby improving destination management. Accordingly, the first objective of this research is to expand and reformulate the concept of intra-destination behaviour by adopting a holistic perspective that includes three dimensions, namely spatial 
movement, time consumption and participation patterns with attractions, to create a model that is then empirically tested.

The earliest studies in the context of intra-destination behaviour focus on the spatiotemporal dimensions in order to discover intra-destination mobility patterns (Hall, 2005; Lew \& McKercher, 2006; McKercher \& Lew, 2004). However, recent studies have highlighted that the traditional spatio-temporal framework does not consider the effect of facts and experiences when examining tourist mobility (Chantre-Astaiza et al., 2019; Han et al., 2018; Xu et al., 2019). Even more recently, Grinberger and Shoval (2019, p.512) introduced a new term to refer to this complex phenomenon, 'tourist activity patterns', 'resulting from the interaction between time-space constraints and the cognitive, social, cultural and emotional tourists' factors". The latter refers specifically to tourists' preferences, motivations, perceptions, cultural background or sociodemographic characteristics, among others, that could influence their behaviour.

Additionally, intra-destination mobility studies have increased largely due to the development of advanced technologies such as tracking technologies (e.g. GPS devices) (Shoval \& Isaacson, 2010). Previous studies on the topic used different methods to collect spatio-temporal data, such as time-space budgets (Debbage, 1991; Pearce, 1988) or direct observation techniques, which included the participant-observer method and non-participatory observation (Hartmann, 1988; Keul \& Kühberger, 1997). However, the rise of tracking technologies and their widespread use in society has stimulated the study of intra-destination mobility in urban contexts (e.g. Caldeira \& Kastenholz, 2020; Kellner \& Egger, 2016; Muñoz-Mazón et al., 2019). Hence, the second objective of this study is to increase the knowledge in this line of research by focusing on the behaviour of cruise visitors in an urban context. Specifically, this research examines the intradestination behaviour of cruise visitors in the city of Valencia, a consolidated urban 
destination (Rausell-Köster et al., 2016) and a Western Mediterranean port of call, being the second most important region in the world in terms of the concentration of cruise traffic (MedCruise, 2019).

Cruise tourism is one of the greatest exponents of mass tourism, as the average cruise ship passenger capacity is around 3000 guests and the largest cruise ships have a total passenger load of up to more than 6000 guests (CLIA, 2018). Thus, when cruise passengers disembark, thousands of visitors are willing to 'consume' the destination in a limited time. This can cause the congestion of certain nodes or points of interest in the destination. Consequently, it is necessary to have an effective strategy to prevent the overcrowding of spaces (Dehoorne \& Petit-Charles, 2013), as this problem has been the trigger of the unsustainability of other mass tourism models (Brida \& Zapata-Aguirre, 2010). For ports, both homeports and ports of call, a high concentration of cruise visitors in certain tourist nodes represents a major concern (Gui \& Russo, 2011; Seraphin et al., 2018; Trancoso González, 2018). Therefore, this study contributes to the understanding of the intra-destination behaviour of cruise visitors, a crucial element for an effective and proper destination management.

\section{Literature review}

\subsection{Intra-destination behaviour: A three-dimensional approach}

Theoretically, spatio-temporal behaviour has been approached from the time geography model constructed by Hägerstrand (1970), where human behaviour is assessed by analysing space and time variables. Hägerstrand's model (1970) identifies the person as the basic unit of research, examining the daily activities, the personal characteristics, the organisational, social and economic context, and where the actions performed are located. Originally, this model was only used to understand the residents' routine 
activities, and it was not until the end of the 20th century when it began to be used in tourism studies (Hall, 2005). Thus, in the tourism field, this model has been used to explain, describe and categorise visitor behaviour within destinations (Shoval \& Isaacson, 2007; Zillinger, 2007). A visitor is presented as an interesting case in the time geography model since the space-time prism is greater due to the freedom of choosing paths in the destination. Therefore, the decisions visitors make regarding activities and travel choice reflect personal desires rather than limitations, so the analysis of spacetime paths allows conclusions to be reached regarding preferences and desires (Grinberger et al., 2014).

The initial studies that analysed intra-destination behaviour were focused on intradestination mobility and spatio-temporal flows (Hall, 2005; Lew \& McKercher, 2006; McKercher \& Lew, 2004). These studies illustrated the visitors' concentration within a destination and their temporal consumption. However, the study of the interaction of visitors with attractions during their visit remains under-researched (Caldeira \& Kastenholz, 2020). This study proposes that the participation patterns or the activities in which visitors are involved when they are visiting the destination have a direct impact on their spatio-temporal patterns. This perspective encapsulates the visitor experience and their level of engagement with attractions (Navarro-Ruiz \& McKercher, 2020; Pine \& Gilmore, 1998; Zhao et al., 2015). Specifically, the effect of participation patterns shows whether visitors prefer to consume more time on specific visitor attractions or distribute their time among different ones. At the same time, this interactional perspective highlights the level of a node's attraction, depending on the visitor concentration and participation patterns. 
Hence, intra-destination behaviour arises from the visitor-destination-attraction relationship. To characterise this behaviour, a three-dimensional approach is needed, the dimensions of which are explained in detail below.

\subsubsection{Spatial dimension}

With respect to the spatial approach, the patterns derived from the visitor movements illustrate the itineraries that visitors choose and the places/points of interest they visit within a destination (Xia et al., 2010). They are reflected in geometric models (Lau, 2007; Lew \& McKercher, 2006; van der Knaap, 1997). These models have been examined from two perspectives: the territorial perspective (from accommodation to attractions) and the linear perspective (from attraction to attraction), which is commonly associated with intra-destination movement patterns (Lew \& McKercher, 2006; McKercher \& Lau, 2008; van der Knaap, 1997). Hence, the linear perspective highlights the individual visitors' paths during their visit.

However, as van der Knaap (1997) proposed, visitor movement patterns are connected by nodes (clusters of attractions, accommodation, infrastructure and services). This idea follows the perceived built environment elements that encapsulate the 'city image' of Lynch (1960). Thus, 'paths' are the channels along which citizens or other users move, while 'nodes' are the strategic spots in a city that are relevant due to thematic characteristics (Lynch, 1960). In the tourism context, the thematic characteristics that compose nodes are the tourist attractions. In line with this idea, Dredge (1999, p.782) also used the term 'nodes' to denote "attraction complexes (i.e. any facility that tourists visit or think about visiting) and service components (i.e. range of facilities to support visitors), which can be categorised from primary to tertiary nodes depending on the level of attraction". Spatially, Leiper (1990) explained that there are three elements in 
the tourist attraction system: the tourist, the attraction nuclei and the markers. Hence, within a tourist node, there are different attraction nuclei, which are the core element that tourists visit, and markers, which are items of information that promote the attraction nuclei or orient visitors to them.

With regard to the study context, cruise tourism is based on a multi-destination trip (Lue et al., 1993), whose ports of call are the destination gateways included throughout the itinerary of the trip. Therefore, each of them has different spatial characteristics depending on their tourist nodes. The spatial dimension of cruise tourism is made up of three geographical areas associated with the administrative boundaries and the level of port attraction: the port area, the port city and the tourist hinterland, which is the space that can be visited by cruise passengers (Esteve-Pérez \& García-Sánchez, 2015).

However, not all port cities have the same area of tourist hinterland since it has a dynamic nature depending on: (1) the development of land transport infrastructure, (2) the distribution of tourist attractions, (3) the development of new attractions near the port, (4) the interests of the visitors, (5) the information provided about what to do in a destination and, mainly, (6) the length of the stopover (De Cantis, Ferrante, Kahani, \& Shoval, 2016; Esteve-Perez \& Garcia-Sanchez, 2015; Thyne, Henry, \& Lloyd, 2015). In this sense, previous studies confirm that the size of the hinterland is different in each port. Jaakson (2004) found that cruise visitors in Zihuatanejo (Mexico) stayed in a confined area near the port terminal, while the studies of De Cantis et al. (2016) in Palermo, Domènech et al. (2020) in Tarragona, and Paananen and Minoia (2019) in Helsinki, all concluded that visitors expand their movement over the destination. In this respect, the following research question is proposed: 
RQ1. Are cruise visitors confined to an area near the port, or do they expand their movements over the tourist hinterland?

\subsubsection{Temporal dimension}

In relation to time, the intra-destination patterns explain the total time spent by visitors and how they schedule it. Bull (1991) and Krakover (2002) explain that the economic discipline endows time with a specific value, understanding it as a limited resource that restricts the ability of individuals to arrange desired activities.

Therefore, time is an ephemeral, dynamic, limited, non-transferable and unrecoverable resource (Cooper, 1981), that stimulates or discourages the intra-destination behaviour of visitors (Lau \& McKercher, 2006; Lu et al., 2016). Hence, the temporal consumption at the destination should be measured with two interdependent variables: the total length of the trip, as well as the total length of the destination stay (Barros \& Machado, 2010; Martinez-Garcia et al., 2018), and the availability and organisation of that time (Zhang et al., 2012).

Previous research has noted that visitors who have limited time in a destination usually visit only iconic or primary attractions, while visitors who stay longer in the same destination expand their movement to secondary and tertiary nodes (Lau, 2007; Tideswell \& Faulkner, 1999). Regarding the study context, cruise visitors have limited time to visit tourist nodes and to enjoy the attractions and activities offered in those destinations. Therefore, the following research question has been asked:

RQ2. Do cruise visitors visit only iconic and primary attractions, restricting their movements and spending their time in primary tourist nodes?

With respect to time scheduling, Chavas et al. (1989) and Walsh et al. (1990) state that there are visitors who conceive the journey as a satisfying and pleasant experience, 
perceiving the journey time as a positive value as opposed to those who perceive it as an opportunity cost. Thus, these visitors probably do not exhaustively or temporally plan what they are going to visit: consequently, their time organisation is more spontaneous. This idea is linked to the study of Hwang and Fesenmaier (2011), who find that many of the activities and attractions that are visited in the destination have not been organised prior to the visit, but are immediate and spontaneous decisions that have an unquestionable impact on the time consumption in the destination.

Accordingly, cruise visitors conceive the journey (cruise itinerary) as a satisfying and pleasant experience. Consequently, the cruise vessel itself, together with the ports of call become co-destinations (Whyte et al., 2018). Hence, to balance the experience of the cruise and ports of call, the operational development of the itinerary consists of docking during the mornings and taking advantage of the nights for inter-port navigations, with the port calls being made between 07:00 and 19:00 (Esteve-Pérez \& García-Sánchez, 2016), giving the passengers time to visit the destination. In this sense, previous research has showed that the limited duration of the stopover is the most influential element in the intra-destination behaviour of cruise visitors since it acts as a restrictive factor (e.g. Brida et al., 2013; De Cantis et al., 2016). However, although the average stopover duration is 10 hours, the average length of visit is around four to five hours (De Cantis et al., 2016; Domènech et al., 2020; Henthorne, 2000). A possible explanation for these short stays (compared to the available time) is that cruise visitors may have not temporally planned the attractions they were going to visit. Thus, the following research questions are asked:

RQ3. Is the length of the call a real constraint for the length of the visit?

RQ4. Does the pre-planning time in the destination affect the length of the visit? 


\subsubsection{Interactional dimension}

According to the analysis of the interaction with the attractions, existing literature has examined the visitors' participation patterns, understanding visitor attractions as experience stages (e.g. Peypoch \& Solonandrasana, 2007; Pine \& Gilmore, 1998; Pizam \& Fleischer, 2005; Urry, 1990; Voase, 2002; Zhao et al., 2015).

Packer and Ballantyne (2016) draw from the literature in tourism and leisure studies to clarify the visitor experience concept and conclude that it is a process of personal interpretation, restricted in time and space, that can be shaped or enhanced, and which has an impact on visitors depending on their level of engagement. Taheri et al. (2019) and Taheri et al. (2014) point out that engagement refers to a sense of involvement produced as a response to stimuli when performing activities, and the nature of these activities can be active or passive.

As far as the nature of activities, Urry (1990), with the 'tourist gaze' notion, was the first to categorise the passive activities that visitors can perform within a destination. In this case, visitors are mere spectators whose main interest is to contemplate the attractions. Another common activity undertaken by visitors when sightseeing that fits perfectly in the passive participation pattern is walking (Hall \& Ram, 2017; Ram \& Hall, 2018). In this case, visitors stroll around the destination as opposed to gazing at attractions. In contrast, Perkins and Thorns (2001) argued that this notion is too passive to describe tourist experiences; therefore, they highlight the notion of 'tourist performance', which incorporates ideas of active bodily involvement through physical, intellectual and cognitive activity. This latter approach has given rise to other studies that highlight the active position of visitors as co-creators of the experience (Campos et al., 2018; Ek et al., 2008). The work by Pine and Gilmore (1998), meanwhile, was 
related to participation patterns and experiences. It theorises on the economy of experience from a business economic perspective approach. These researchers constructed a model showing four possible scenarios of the experience based on participation performance (from active to passive) and the visitors' connection with the environment (from absorption to immersion).

Hence, in relation to the activities pursued, the visitor participation patterns will be varied (Kim et al., 2007; Zoltan \& McKercher, 2015), from activeness to passiveness (Izquierdo \& Samaniego, 2011; Pizam \& Fleischer, 2005). Active participation is related to visitors who have a special interest in attractions and are identified as 'spacesearchers' (Walmsley \& Jenkins, 1991). These visitors are seen as more active, curious and adventurous people who move across a wider area, visiting more places and tending to participate actively in the attractions or activities (McKercher \& Lau, 2008; Voase, 2002; Walmsley \& Jenkins, 1991). They also look for unknown experiences that enable them to evade their routine life (Khairi \& Ismail, 2015). Therefore, these visitors need to fully enjoy the attractions they visit during the time they deem necessary to satisfy their expectations. In contrast, passive participation is related to visitors who have a general interest in attractions and are known as 'space-sitters' (Walmsley \& Jenkins, 1991). These visitors act as spectators whose characteristics are based on reacting in a trivial way to the destination supply, which entails minimising exploratory trips (Walmsley \& Jenkins, 1991), moving within a confined area where they remain in a familiarity bubble (McKercher \& Lau, 2008) and passively experiencing the attractions by gazing at them or wandering around (Khairi \& Ismail, 2015; Voase, 2002). In summary, these visitors are happy with a quick and superficial visit of as many visitor attractions as possible that they can consume in a limited time in an area where they feel secure. 
Participation patterns are therefore the combined result of the different interactions with the attractions within the same tourist node. When visitors have a special interest in attractions and need to be bodily involved (physically, intellectually or cognitively), the participation pattern is active (engaged activity patterns). In contrast, when visitors have a general interest in attractions and prefer to stroll around the node contemplating the attractions, the participation pattern is passive (general sightseeing patterns).

In relation to activities performed by cruise visitors, Gutberlet (2019) and Li (2019) point out that the vast majority of cruise passengers superficially contemplate the destination because they selectively consume the attractions and services quickly and intensely in a small part of the city, above all in historical centres. De Cantis et al. (2016) and Domènech et al. (2020) found in their studies in Palermo and Tarragona that cruise visitors tend to visit the hotspots located in the city centres. Brandajs and Russo (2019) also examined how cruise visitors intensely consume public spaces such as the squares in Barcelona. In contrast, Andriotis and Agiomirgianakis (2010) conclude in their study on Heraklion (Crete) that independent cruise passengers prefer to visit the modern part of the city instead of the city centre, where the cultural attractions are located. Therefore, the next research question is as follows:

RQ5. Do cruise visitors perform passive activities more related to general sightseeing patterns, or do they show a more active behaviour?

\section{Methodology}

\subsection{Study context}

The study context chosen to carry out the research is the city of Valencia, the third largest municipality in Spain in terms of population. Valencia has experienced a considerable transformation and has become an important urban destination in Europe 
(Rausell-Köster et al., 2016) owing to several public policies related to new infrastructures, attractions and marketing strategies (Puche-Ruiz \& Obiol-Menero, 2011; Salom-Carrasco \& Pitarch-Garrido, 2017). In this context, the Strategic Tourism Plans in Valencia (Turismo Valencia, 2011, 2017) propose cruise tourism as an interesting emerging product, as it is located in the Western Mediterranean region. The official statistics in 2019 reveal that Valencia was the fourth largest Spanish Mediterranean port, as the city received 435,616 cruise passengers (Ministerio de Fomento, 2019). However, the local community has begun to perceive risks generated by the cruise activity in this city (Del Chiappa et al., 2018).

\subsection{Research design}

This study employs a multi-method approach, illustrated in Figure 1, in order to triangulate the data obtained (Brewer \& Hunter, 2006; Creswell, 2014; Tashakkori \& Teddlie, 2003). This approach has been used in previous studies on this topic (e.g. Beeco et al., 2013; Lau \& McKercher, 2006; Y. Li et al., 2019). Subsequently, the research employs questionnaires, trip diaries and GPS tracking technologies. The use of GPS devices is justified by the reliability of the spatial-temporal data they record, while the trip diaries allow qualitative information to be gathered on the activities carried out and the time consumed in each of the attractions visited (Shoval \& Isaacson, 2010). As for the questionnaires, there is a broad consensus about their use as a method to collect socio-demographic data, visitor destination knowledge and behavioural attitudes, among other data (Veal, 2006). Therefore, the combined use of methods that integrate data from GPS devices and traditional surveys provides a combined dataset that rigorously reflects this complex phenomenon (Y. Li et al., 2019).

Figure 1. Methodological framework of the study 


\section{[Insert Figure 1]}

Source: Authors

Information regarding cruise arrivals and provision of number of passengers was provided by the Port Authority of Valencia. The data were collected in the port of Valencia between April and June 2018, the high season of cruise arrivals. Cruise visitors were selected by implementing stratified random sampling through a random selection procedure, with strata given by onshore visit choice. According to data from the Port Authority of Valencia, $80 \%$ were independent visitors and $20 \%$ were guided visitors in organised tours.

The interviewers approached the independent visitors twice, right after they disembarked and when they returned to the terminal. In the first stage, those who agreed to participate were asked to answer an initial questionnaire about their sociodemographic characteristics, destination knowledge and pre-planning information (categorical variables). They were then given GPS data-logging equipment, a small device that they could easily carry around which recorded the position every 15 seconds, and also an official map with a trip diary attached in which the subjects were asked to fill in the attractions visited and activities performed. In the second stage, when participants returned to the cruise terminal, they delivered the GPS device and the trip diary and answered a final (short) questionnaire about their experience, spatial behaviour during their visit and group composition (categorical variables). Guided visitors were approached after finishing their visit when they returned to the terminal. The questions were the same to those asked to independent visitors, but the GPS datalogging equipment was held by the tour guides given the impossibility to contact guided visitors before the tour. Given that onshore visits are strictly programmed and confined to specific geographical spaces, it was assumed that the space covered and the time 
spent by visitors would not deviate too much from the one by the tour guide (the person wearing the GPS device).

\subsection{Data analysis}

In the first phase, the spatio-temporal patterns of cruise visitors were differentiated according to the number of nodes visited, thereby leading to a different spatial behaviour. Cartographic methods were used by applying QGIS 3.4.5 Madeira. The GPS data were analysed by using cartographic methods to define several mobility patterns, and trip diaries were employed to verify those patterns. After checking the tracks and diaries, visitors were classified between those who visited a single node or multiple nodes. The results of this analysis show that cruise visitors tend to move to four tourist nodes, which include diverse attractions: (1) Bioparc, a zoo immersion experience, (2) the city centre, where most of the cultural attractions are located, (3) the City of Arts and Sciences (CAC), an avant-garde architectural complex, and (4) Marina Realpromenade (see Figure2).

Figure 2. Valencia and its tourist nodes

\section{[Insert Figure 2]}

Source: Authors

A single node indicates that cruise passengers visit one of the several Valencian nodes, consuming all of their time in them, whereas multiple nodes indicate that cruise passengers visit two or more nodes, distributing their available time between them. Hence, these tracking devices also offered reliable data about temporal patterns, which were used to examine the length of visit.

In the second phase, data from the trip diaries were examined using the content analysis method to determine which participation pattern was performed. Thus, three possible 
modalities were detected: (1) active visit to a single or multiple attractions within the same node, (2) a contemplative panoramic visit or general sightseeing (on foot or by bus) of the node or (3) the combination of an active visit to specific attractions and the general sightseeing of the rest of the node. Accordingly, the active visit was considered when visitors expressly paid for an attraction ticket since they had a special interest in visiting it or when visitors used learning materials such as audio-guides or performed physical activities such as jet skiing. In contrast, those attractions which were visited without the purchase of a ticket were considered as a contemplative pattern since it was not known whether there was a particular intention. The general sightseeing modality therefore refers to those visual or contemplative itineraries whose main activity was to walk, gaze and take photos, without gaining further knowledge about the attraction. This is also the case of the general sightseeing by the hop-on hop off bus service and the panoramic onshore excursions. As a result, visitors were classified in terms of their spatio-temporal flows and participation patterns, which in combination help to identify homogeneous patterns.

In the third phase, intra-destination behaviour maps were created by applying Shoval's (2008) grid technique. Shoval proposed the division of the study context into cells to examine the number of people and the average time they spent within the same cell. Accordingly, a grid of $50 \mathrm{~m}^{2}$ cells was created in the study area. The map illustrates the visitor concentration by colour gradation (with light green indicating low intensity and red indicating high intensity), whereas the average time consumption in the cell was illustrated by the height of the columns.

Finally, the different clusters grouped by homogeneous intra-destination behaviour were characterised and compared in accordance with socio-demographic profiles, trip characteristics and visitor experience. Furthermore, Pearson's chi-square test was used 
to evaluate the dependence relationship between variables derived from questionnaires and the intra-destination behaviour obtained.

\section{Results}

Research was conducted over the course of 35 days. Weekdays were the most common days for receiving cruises; the cruise ships usually came from Barcelona or Mallorca, and the average length of the call was eight and a half hours. The study included 627 cruise visitors, and the final valid sample was 503. This reduction is attributed to the data cleaning applied to the methods used. Specifically, those individuals who answered both the initial and the final questionnaires, who filled out the trip diary and whose GPS tracks did not show temporal jumps in their position due to the urban canyon effect were valid (Ferrante, De Cantis, \& Shoval, 2018).

The results obtained therefore allowed the researchers to distinguish five cruise-visitor intra-destination behaviour patterns according to their spatio-temporal movements and participation patterns (see Table 1). The sample was almost equally divided between passengers who visited a single node and those who visited multiple nodes. The participation patterns differed, however, between them. Cruise visitors who stayed in a single node tended to perform passive activities (panoramic and contemplative visits), while cruise visitors who visited multiple nodes prefered to combine immersive/active activities and contemplative ones within the nodes.

Table 1. Cruise visitor intra-destination behaviour patterns

\section{[Insert Table 1]}

Maps of each intra-destination behaviour are now presented and discussed Figure 3 depicts visitors who moved to a single node and actively visited the attractions, accounting for $8.3 \%$ of the total sample. In this pattern, flows are concentrated in 
specific attractions, instead of being dispersed around the node. The highest intensity of visitors was obtained in the CAC, particularly at the Oceanographic (an aquarium), which almost $70 \%$ of cruise passengers from this group visited. Likewise, it may also be observed that certain attractions in the city centre were visited by between 15 to $30 \%$, and the other nodes hosted a smaller percentage but the average time consumed was higher. The average length of stay was four hours and 40 minutes. In detail, the longest average length of time spent at attractions was at the Oceanographic (four hours), followed by the Bioparc (three hours 30 minutes) and the sea-promenade (three hours 20 minutes). With respect to the activity patterns, the results reveal that $73.4 \%$ chose to visit these attractions both inside and out, obtaining a complete picture of them. More specifically, $56.3 \%$ visited the attractions with guides or audio guides, while $15.6 \%$ prefered to contemplate them and take photos.

Figure 4 illustrates visitors who moved to a single node and passively visited the attractions, accounting for $32.3 \%$ of the total sample. The most intense concentration occured in the city centre node ( $80 \%$ of visitors in particular POIs). Moreover, the attractions with the highest intensity of visitors were the public squares, which have become hotspots. In this case, the concentration in the CAC was medium, as visitors prefered to move to the city centre. The average length of stay was four hours, and the findings show that visitors who moved to the city centre distributed their time between cultural attractions (an average of 20 minutes on each, regardless of whether they were cultural attractions or public places) while in the CAC, visitors wandered around, staying for one hour and 30 minutes on average. In terms of activity patterns, $76.3 \%$ chose to visit attractions from the outside. Additionally, $47.6 \%$ contemplated and photographed them, while $24.4 \%$ prefered to walk while taking snapshots of attractions. 
Figure 5 shows visitors who moved to a single node and combined active and passive participation patterns, accounting for $11.9 \%$ of the total sample. The highest concentration of visitors was in the city centre. Specifically, between $60 \%$ and $80 \%$ of visitors discovered the Cathedral (visit duration around 40 minutes) and its two adjoining squares, the Virgin and Queen Squares (stopover duration around 40 minutes). The average length of visit was four hours and 40 minutes. Regarding the CAC, a lower intensity of visitors was observed, although the average length of stay was higher than in the historical centre. In particular, the Oceanographic has an average stay of three hours and 40 minutes. Concerning the participation patterns, $60.9 \%$ visited attractions from the outside, while $29.1 \%$ discovered them both inside and out. On the other hand, $33.5 \%$ preferred to contemplate, strolled around and took photos of the attractions, $40.3 \%$ discovered attractions through an excursion organised by the shipping company and $15.4 \%$ interacted with them, actively entering them or using learning materials.

Figure 6 represents visitors who moved to multiple nodes where, in each of them, a panoramic visit was made (on foot or by bus), accounting for $15.2 \%$ of the total sample. In this pattern, more than $75 \%$ of these visitors stayed in the historical centre, especially in the city squares. Similarly, this pattern also revealed the presence of visitors in different attractions such as the Turia riverbed (average visit duration of one and a half hours), and the hop-on hop-off tourist bus (average visit duration of two hours). Finally, the Marina Real-promenade had higher ratios of temporal consumption (two and a half hours). To sum up, the average length of stay was five hours 30 minutes, during which $81.3 \%$ of cruise passengers prefered to visit the attractions from the outside. Thus, the interaction results show that $47.7 \%$ contemplated and photographed the attractions, 
$26.3 \%$ chose to take a walk and took photos and $7.8 \%$ discovered the attractions through an excursion organised by the shipping company.

Figure 7 depicts visitors who moved to multiple nodes, where visitors combined active and passive participation patterns, accounting for $32.2 \%$ of the total sample. In this pattern, there was a greater distribution of flows (in fact, $5.2 \%$ of this group expanded its movements beyond the port city, visiting other municipalities). Additionally, there is evidence of visitors in all tourist nodes, even at other nodes, such as the Mestalla football stadium. Regarding concentration, more than $50 \%$ of the sample visited the city centre and the CAC. Meanwhile, the average length of stay was five hours, and the average duration indicates that visitors stayed longer in Oceanographic (three hours and 30 minutes), CAC (two hours and 30 minutes), Bioparc (two hours), Mestalla (one hour and 45 minutes) and the historical squares (40 minutes). In relation to participation patterns, the results reveal that $67.7 \%$ visited the attractions just from the outside, while $32.3 \%$ discovered them inside and outside. Furthermore, it is observed that $65.6 \%$ visited them through an excursion organised by the shipping company, $19.9 \%$ contemplated, wandered around and photographed them, while $7.2 \%$ said that they actively interacted with them.

\begin{tabular}{|l|l|}
\hline [Insert Figure 3] & [nsert Figure 4] \\
\hline [Insert Figure 5] & {$[$ Insert Figure 6] } \\
\hline [Insert Figure 7] & {$[$ Insert Figure 8] } \\
\hline
\end{tabular}

Source: Authors

After obtaining homogeneous intra-destination behaviour patterns in terms of the spatio-temporal flows and participation patterns, the groups were characterised using variables collected through questionnaires and reported in Table 2 . These variables were 
selected following previous literature that compares or characterise cruise visitor behaviour, such as familiarity (Brida et al., 2012; Sanz-Blas et al., 2019), onshore visit choice (Navarro-Ruiz et al., 2019; Sanz-Blas et al., 2019), information search (De Cantis et al., 2016; Domènech et al., 2020) and itinerary intention (Andriotis \& Agiomirgianakis, 2010; Jaakson, 2004), among others.

Table 2. Summary of participant characteristics derived from questionnaires according to homogenous intra-destination behaviour

\section{[Insert Table 2]}

Table 2 shows interesting differences between the intra-destination behaviours of cruise visitors in this urban destination. Pearson's chi-square tests indicate that the variables that have a dependence relationship with intra-destination behaviour are age, country of residence, onshore visit choice, attraction prior interest, itinerary intention, time schedule, attractions visited and length of visit. Thus, in this study context, these factors stimulated the intra-destination behaviour of cruise visitors.

Specifically, with regard to the socio-demographic profiles, elderly participants were associated with different patterns, whereas younger individuals prefered to move to multiple nodes, doing general sightseeing. Moreover, participants who moved to a single node, visiting it actively or passively, were mainly from Europe, while in the rest of the patterns there were also participants from other regions. With respect to the trip characteristics and visitor experience, meanwhile, the results highlight that independent cruise visitors were more represented in general sightseeing behaviours, whereas guided visitors were associated with the combination of participation patterns in multiple nodes. Furthermore, it may be observed that cruise visitors who actively visited the 
attractions or combined participation patterns had a prior interest in the attractions, scheduled their available time and planned their itinerary, while cruise visitors who preferred sightseeing were more spontaneous in their itineraries and time consumption. Another expected result concerns the average length of stay, as cruise passengers who moved to multiple nodes stayed longer than cruise visitors who moved to a single node. Likewise, cruise passengers who tended to interact actively stayed longer within the destination than those who were liable to stroll around and gaze at attractions. Finally, the findings show that cruise visitors, in general, were totally satisfied with the destination and had a high intention to recommend it. However, the intention to return was lower.

\section{Discussion}

The results obtained suggest that cruise visitors do not behave in the destination or experience and consume it in a homogeneous way. Moreover, not all of them share the same profile. Consequently, cruise passengers should be considered as a heterogeneous segment with different motivations, interests and behaviour patterns. This result is crucial for destination management since it is likely that various actions are needed depending on the different behaviours. In fact, there are cruise visitors who have a special interest in attractions and want to interact with them actively by being bodily or cognitively involved, while there are others whose main activity pattern is to wander around while contemplating and taking photos of the attractions.

As for the first and second research questions, the findings of this study confirm that cruise visitors in Valencia stay mainly in the port city, as it is endowed with iconic and primary attractions, reinforcing the idea of urban cruise visitors (Navarro-Ruiz et al., 2019). Indeed, just 5.2\% expanded their movements beyond the port city; these were 
guided cruise visitors. Therefore, policy makers should encourage independent visitors to expand their itineraries. Within Valencia, four areas have been defined as the different tourist nodes visited. In this respect, the outcomes contradict the idea that cruise visitors are confined to an area near the port (Jaakson, 2004) and reinforce the results from De Cantis et al. (2016) and Domènech et al. (2020), who found that cruise passengers expand their movements between and within the tourist nodes of the city. In the study context, almost $75 \%$ of cruise participants focus on visiting the main tourist nodes: the city centre, where the main cultural attractions are located, and they also discover (though less intensely) the City of Arts and Sciences, the modern area of the city, with the greatest intensity found in specific attractions. Hence, it is confirmed that multi-destination trippers prefer to visit iconic attractions and primary nodes (McKercher et al., 2006).

Additionally, information provided could have played an important role, especially for those visitors staying in a single node with an active visit. The findings reveal that a large number of people who visited the Oceanographic had prior information about the destination. Hence, as pointed out by Hospers (2009), city marketing actions seem to have an impact on tourist behaviour, guiding their interests and movements. Furthermore, the high concentration of cruise passengers in the historical centre is in line with the conclusions of De Cantis et al. (2016), Domènech et al. (2020) and Paananen and Minoia (2019) and opposes those of Andriotis and Agiomirgianakis (2010), as cruise passengers do not prefer to visit the modern area. Likewise, the mobility behaviour of cruise visitors in Valencia also reveals the high consumption of public spaces when they visit the destination, as indicated by Brandajs and Russo (2019). Hence, it can be assumed that cruise visitors in Mediterranean ports expand their movements more than those who visit Caribbean ports. 
Regarding the third and fourth research questions, although the spatial patterns indicate that the highest visitor concentrations occur in the historical centre of the city, the time consumption does not follow this inclination. In fact, temporal consumption is higher in the rest of the nodes such as the CAC, Bioparc or Marina Real-promenade. It can therefore be concluded that cruise visitors spend more time in newly created attractions such as the Bioparc (zoo) or Oceanographic (aquarium), rather than at cultural attractions located in the historical centre, where they distribute their time visiting several of them.

According to time spent in the destination, the average length of visit was four to five hours, depending on the intra-destination pattern, whereas the average length of the call is eight and a half hours. Therefore, findings confirm that during the total length of the call, cruise passengers spent half their time visiting the destination, and the rest of the time they prefered to stay on board even though the cruise ship was docked. These results are similar to those of De Cantis et al. (2016), Domènech et al. (2020) and Henthorne (2000). Hence, the time restriction of the call does not affect the length of visit that much, as cruise visitors could extend their time visiting the destination. This result contradicts the assumption that length of call is the most restrictive factor in terms of intra-destination behaviour. Regarding pre-planning times of visits, the outcomes also highlight that cruise visitors who have temporally planned the attractions they were going to visit stay a little bit longer in the destination (30-40 minutes) than those who prefer to visit the destination spontaneously. Consequently, it can be assumed that prior temporal organisation does not affect the length of the visit because there are not significant differences between them.

With regard to the fifth research question, the participation pattern findings reflect that $8.3 \%$ of participants took part in active types of activities, $47.5 \%$ of participants 
prefered to visit the tourist nodes by way of general sightseeing on foot or by bus, and $44.1 \%$ of cruise visitors chose to combine active and passive activities within the nodes visited. As for the activities carried out, the majority of cruise visitors prefered to visit attractions just from the outside, with the most frequent activities being wandering around, contemplating and taking photos. This reinforces the 'collective gaze' proposed by Urry (1990), as some cruise visitors do not usually behave actively with the attractions. Thus, the results of this study partially support the outcomes of Gutberlet (2019) and Li (2019), who conclude that the majority of cruise visitors take a superficial glance at the destination through passive activities. However, the results also reveal that other cruise participants prefer to bodily or cognitively engage with the attractions through guides, audio-guides, excursions, sport activities, and so on. Accordingly, not all cruise visitors have a superficial experience.

Finally, this study highlights the different visitor profiles according to the intradestination behaviour patterns. Significant differences have been observed between groups regarding the onshore visit choice, their prior interest in attractions, the schedule of their available time and the planning of their itinerary. These findings should be considered by policy makers when developing public actions.

\section{Conclusions}

Understanding how visitors behave within a destination is extremely important for destination management and planning in order to prevent and mitigate the possible negative impacts. In the cruise tourism context, this diagnosis is even more relevant since cruise visitors consume the destination, its attractions and its services in a limited period of time due to the typology of cruises as multi-destination trips (Lau, 2007; Oppermann, 1995; Tideswell \& Faulkner, 1999). 
Previous research on intra-destination behaviour has mainly been based on analysing spatio-temporal flows or mobility patterns, while, until now, participation patterns have been studied in a secondary stage (Chantre-Astaiza et al., 2019; Grinberger \& Shoval, 2019; Xu et al., 2019). The main theoretical contribution of this paper is therefore the proposal of a consistent three-dimensional framework that integrates spatial movement, temporal consumption and interaction with attractions. To strengthen this original theoretical approach, this study empirically examines, in the context of cruises, the classic linear models proposed by van der Knaap (1997), Lew and McKercher (2006) and McKercher and Lau (2008) systematised by tourist nodes (Dredge, 1999; van der Knaap, 1997). Therefore, an integrated vision of intra-destination mobility is obtained. In this way, the concentration and flow distribution within nodes is illustrated, offering information on the functional spatial cohesion of the tourism phenomenon. The participation and activity patterns suggested by Grinberger and Shoval (2019) and Zoltan and McKercher (2015), meanwhile, have been considered to classify cruise visitors depending on how they interact with attractions: as mere spectators/space-sitters (Urry, 1990; Walmsley \& Jenkins, 1991) or co-creators of their experience/spacesearchers (Ek et al., 2008; Perkins \& Thorns, 2001; Walmsley \& Jenkins, 1991), which directly affect the spatio-temporal flows. Hence, this is the first study which sheds light on the spatio-temporal mobility and participation patterns of cruise visitors from active to passive involvement in order to classify homogenous intra-destination behaviour patterns analytically and holistically.

The theoretical approach described above required the implementation of an innovative methodological design that enabled the researchers to contrast data from the three dimensions. This methodological contribution is based on triangulating data collected from different instruments: GPS devices, questionnaires and trip diaries. Accordingly, 
accurate spatio-temporal data are obtained through GPS devices, reliable activity patterns in each attraction are collected by trip diaries, and socio-demographic, trip factors and experience variables are obtained through questionnaires. Furthermore, this multimethod approach allowed these diverse data to be collected, analysed, triangulated and combined, thereby obtaining different intra-destination behaviour patterns, and to characterise cruise visitor profiles. As Li et al. (2019) emphasise, the combination of methods provides accurate results of visitor behaviour within destinations.

Nonetheless, this study has some limitations. First, the sampling period implies that it is not possible to infer the total population of cruise passengers who visit Valencia, since a longitudinal study would be required. Another limitation is related to the total number of cruise passengers who arrive in Valencia, as there is a lack of knowledge regarding the number of passengers who remain on-board. Furthermore, regarding data collection, the urban canyon effect produced in narrow streets, which implies a loss of signal, is another limitation. With respect to the trip diaries, participants could have forgotten to record certain activities in which they took part that they did not consider important. Although three methods were used to collect data, it would have been interesting to include in-depth conversation with participants to enrich the results and add extra nuance. Finally, the results cannot be generalised for the whole cruise tourism context, as Valencia has its own destination idiosyncrasies.

In order to extend this research, it would be interesting to replicate the study in other urban Mediterranean ports to compare the results. Furthermore, this research has not examined the intra-destination behaviour impacts on the economy, the environment and the welfare of residents; a future line of research would be required for destination management. Along these lines, it would be interesting to analyse the cruise visitor experience from a qualitative perspective. The findings reveal, meanwhile, that onshore 
visit choice (independent versus guided) affects intra-destination patterns; thus, further research is needed in order to compare the two groups. As for the intervening factors, an exhaustive review of all the variables that influence intra-destination behaviour is required to establish a systematisation which allows the researchers to conduct an empirical joint evaluation. Additionally, it would be interesting to compare cruise visitor intra-destination behaviour with other multi-destination trippers and with other urban or cultural tourists. Finally, another future research line would reside in discerning whether the actions performed by DMO have led to considerable intradestination behaviour changes.

In short, the results of this research might be very useful to cruise-line companies as well as destination managers. Therefore, it helps destinations to gain knowledge about cruise visitor intra-destination behaviour within their boundaries and beyond them. Although this research has focused on cruise visitor behaviour, the theoretical framework and the empirical design can serve as a foundation for future research evaluating other segments because the accurate measurement of spatio-temporal flows and participation patterns with attractions could guide policy makers to implement effective actions in order to prevent potential negative impacts (e.g. overcrowding) and maximise the contribution of tourism to the social welfare of the destination.

However, the cruise industry and cruise destinations are facing an enormous challenge in terms of recovery from the current COVID-19 pandemic. While other forms of tourism have started to operate in the new normal, cruise companies will probably have to wait longer to get back to business. On the one hand, social distance and hygiene are hard to ensure in cruise ships, as they are mainly conceived to host as many people as possible in a limited (small) space, where queueing is the predominant organisational tool (e.g. buffet, disembarking and attractions). On the other hand, seniors are one of 
their main segments, the age group most threatened by the virus. Moreover, some researchers are calling for a local-oriented, restricted and more sustainable recovery of tourism, where cruise tourism would not easily fit in (Renaud, 2020) due to its contribution to overtourism processes and the growing perception of the cruise tourism sector as one example of the injustices and exploitations of the tourism industry operating under neoliberalism. This is evidenced in the health risks experienced by workers in the COVID-19 crisis, refused entry into most ports as a consequence of their work under flags of convenience to avoid economic, social and environmental regulations (Higgins-Desbioles, 2020). The cruise industry is confronted with a highly uncertain scenario, and so is the Mediterranean region (Coulter, 2020). In the near future, some destinations will have to decide if and how to allow cruise ships to operate again, and a broad and clear picture of what was happening under normal circumstances will be essential to take post-COVID-19 informed decisions. Thus, while the main results of the present study are expected to hold, some future research avenues can also be highlighted: (1) analysing the intra-destination visitors' flows after the pandemic to detect the variations (if any) and the effects of demand-related factors (e.g. visitors' perception of security at destination) and destination-related measures (e.g. signage, health protocols and crowd control measures); and (2) examining the changes in residents' perceptions towards cruise tourism (e.g. fear of infection). Finally, since tourists will perceive less congested ports as safer, emerging destinations such as Valencia could take advantage of this situation to attract more cruise visitors.

\section{References}

Alegre, J., \& Pou, L. (2006). The length of stay in the demand for tourism. Tourism Management, 27(6), 1343-1355. 
Andriotis, K., \& Agiomirgianakis, G. (2010). Cruise visitors' experience in a Mediterranean port of call. International Journal of Tourism Research, 12, 390404.

Barros, C. P., \& Machado, L. P. (2010). The length of stay in tourism. Annals of Tourism Research, 37(3), 692-706.

Beeco, J. A., Huang, W. J., Hallo, J. C., Norman, W. C., McGehee, N. G., McGee, J., \& Goetcheus, C. (2013). GPS tracking of travel routes of wanderers and planners. Tourism Geographies, 15(3), 551-573.

Brandajs, F., \& Russo, A. P. (2019). Whose is that square? Cruise tourists' mobilities and negotiation for public space in Barcelona. Applied Mobilities, 1-25.

Brewer, J., \& Hunter, A. (2006). Foundations of multimethod research: Synthesizing styles. Thousand Oaks: Sage.

Brida, J. G., Bukstein, D., Garrido, N., Tealde, E., \& Zapata, S. (2010). Impactos económicos del turismo de cruceros: Un análisis del gasto de los pasajeros de cruceros que visitan el Caribe colombiano. Estudios Y Perspectivas En Turismo, 19(5), 607-634.

Brida, J. G., Pulina, M., Riaño, E., \& Zapata-Aguirre, S. (2012). Cruise passengers' experience embarking in a Caribbean home port: The case study of Cartagena de Indias. Ocean and Coastal Management, 55, 135-145.

Brida, J. G., \& Zapata-Aguirre, S. (2010). Cruise tourism: Economic, socio-cultural and environmental impacts. International Journal of Leisure and Tourism Marketing, l(3), 205-226.

Bryce, D., Curran, R., O’Gorman, K., \& Taheri, B. (2014). Visitors' engagement and 
authenticity: Japanese heritage consumption. Tourism Management, 46, 571-581.

Bull, A. (1991). The economics of travel and tourism. Melbourne: Longman.

Caccomo, J. L., \& Solonandrasana, B. (2002). Réflexions autour du concept de 1'attraction touristique: Analyse et taxonomie. Téoros, Revue de Recherche En Tourisme, 21(3), 68-71.

Caldeira, A. M., \& Kastenholz, E. (2020). Spatiotemporal tourist behaviour in urban destinations: A framework of analysis. Tourism Geographies, 22(1), 22-50.

Campos, A. C., Mendes, J., Oom, P., \& Scott, N. (2018). Co-creation of tourist experiences: A literature review. Current Issues in Tourism, 21(4), 369-400.

Chantre-Astaiza, A., Fuentes-Moraleda, L., Muñoz-Mazón, A., \& Ramirez-Gonzalez, G. (2019). Science mapping of tourist mobility 1980-2019: Technological advancements in the collection of the data for tourist traceability. Sustainability, 11(17), 4738.

Chavas, J.P., Stoll, J., \& Sellar, C. (1989). On the commodity value of travel time in recreational activities. Applied Economics, 21(6), 711-722.

CLIA. (2018). 2019 Cruise Trends \& Industry Outlook. Retrieved 25.03.20. from: https://cruising.org/-/media/research-updates/research/clia-2019-state-of-theindustry-presentation-(1).pdf

Cooper, C. P. (1981). Spatial and temporal patterns of tourist behaviour. Regional Studies, 15(5), 359-371.

Coulter, A. (2020). When will the Mediterranean open up to cruises? USA Today. Retrieved 22.06.20 from: https://eu.usatoday.com/story/travel/cruises/2020/06/16/mediterranean-cruises- 
when-popular-region-open-ships/3194984001/

Creswell, J. (2014). The selection of a research approach. In Creswell, J. W. (Ed.), Research design: qualitative, quantitative, and mixed methods approaches. (pp. 323). Thousand Oaks: Sage.

De Cantis, S., Ferrante, M., Kahani, A., \& Shoval, N. (2016). Cruise passengers' behavior at the destination: Investigation using GPS technology. Tourism Management, 52, 133-150.

Debbage, K. G. (1991). Spatial behavior in a Bahamian resort. Annals of Tourism Research, 18(2), 251-268.

Dehoorne, O., \& Petit-Charles, N. (2013). Tourisme de croisière et industrie de la croisière. Études Caribéennes, 18.

Del Chiappa, G., Lorenzo-Romero, C., \& Gallarza, M. (2018). Host community perceptions of cruise tourism in a homeport: A cluster analysis. Journal of Destination Marketing \& Management, 7, 170-181.

Domènech, A., Gutiérrez, A., \& Anton Clavé, S. (2020). Cruise passengers'spatial behaviour and expenditure levels at destination. Tourism Planning and Development, 17(1), 17-36.

Donaire, J. A., Galí-Espelt, N., \& Royo-Vela, M. (2015). El uso de GPS para el análisis del comportamiento espacio-temporal de los turistas. Pre-test en el Valle de Boí. Cuadernos de Turismo, 35, 117-131.

Ek, R., Larsen, J., Hornskov, S. B., \& Mansfeldt, O. K. (2008). A dynamic framework of tourist experiences: Space-time and performances in the experience economy. Scandinavian Journal of Hospitality and Tourism, 8(2), 122-140. 
Esteve-Pérez, J. A., \& García-Sánchez, A. (2015). Cruise market: Stakeholders and the role of ports and tourist hinterlands. Maritime Economics \& Logistics, 17(3), 371388.

Esteve-Pérez, J. A., \& García-Sánchez, A. (2016). Key stakeholders in cruise traffic: An application to Spanish cruise ports. In Kozak M., \& Kozak N. (Eds), Tourism and Hospitality Management (Advances in Culture, Tourism and Hospitality Research, vol.12) (pp. 81-93). Bingley: Emerald.

Fennell, D. A. (1996). A tourist space-time budget in the Shetland Islands. Annals of Tourism Research, 23(4), 811-829.

Ferrante, M., De Cantis, S., \& Shoval, N. (2018). A general framework for collecting and analysing the tracking data of cruise passengers at the destination. Current Issues in Tourism, 21(12), 1426-1451.

Gitelson, R. J., \& Crompton, J. L. (1984). Insights into the repeat vacation phenomenon. Annals of Tourism Research, 11 (2), 199217.

Gokovali, U., Bahar, O., \& Kozak, M. (2007). Determinants of length of stay: A practical use of survival analysis. Tourism Management, 28(3), 736-746.

Grinberger, A. Y., \& Shoval, N. (2019). Spatiotemporal contingencies in tourists' intradiurnal mobility patterns. Journal of Travel Research, 58(3), 512-530.

Grinberger, A. Y., Shoval, N., \& McKercher, B. (2014). Typologies of tourists' timespace consumption: A new approach using GPS data and GIS tools. Tourism Geographies, 16(1), 105-123.

Gui, L., \& Russo, A. P. (2011). Cruise ports: A strategic nexus between regions and global lines - evidence from the Mediterranean. Maritime Policy \& Management, 
$38(2), 129-150$.

Gutberlet, M. (2019). "In a rush": Time-space compression and its impacts on cruise excursions. Tourist Studies, 19(4), 520-548.

Hägerstrand, T. (1970). What about people in regional science? Papers in Regional Science, 24(1), 7-24.

Haldrup, M. (2004). Laid-back mobilities: Second-home holidays in time and space. Tourism Geographies, 6(4), 434-454.

Hall, C. M. (2005). Time, space, tourism and social physics. Tourism Recreation Research, 30(1), 93-98.

Hall, C. M., \& Ram, Y. (2019). Measuring the relationship between tourism and walkability? Walk score and English tourist attractions. Journal of Sustainable Tourism, 27(2), 223-240.

Han, H., Kim, S. (Sam), \& Otoo, F. E. (2018). Spatial movement patterns among intradestinations using social network analysis. Asia Pacific Journal of Tourism Research, 23(8), 806-822.

Hartmann, R. (1988). Combining field methods in tourism research. Annals of Tourism Research, 15, 88-115.

Henthorne, T. L. (2000). An analysis of expenditures by cruise ship passengers in Jamaica. Journal of Travel Research, 38(February), 246-250.

Higgins-Desbiolles, F. (2020). Socialising tourism for social and ecological justice after COVID-19. Tourism Geographies, 22(3), 1-14.

Hospers, G. J. (2009). Lynch, Urry and city marketing: Taking advantage of the city as 
a built and graphic image. Place Branding and Public Diplomacy, 5(3), 226-233.

Hwang, Y. H., \& Fesenmaier, D. R. (2011). Unplanned tourist attraction visits by travellers. Tourism Geographies, 13(3), 398-416.

Izquierdo, C. C., \& Samaniego, M. J. G. (2011). Strengthening members' relationships through cultural activities in museums. Journal of Leisure Research, 43(4), 560588.

Jaakson, R. (2004). Beyond the tourist bubble? Cruiseship passengers in port. Annals of Tourism Research, 31(1), 44-60.

Kellner, L., \& Egger, R. (2016). Tracking tourist spatial-temporal behavior in urban places, a methodological overview and GPS case study. In Inversini, A., \& Schegg, R. (Eds), Information and Communication Technologies in Tourism 2016 (pp. 481-494). Cham: Springer.

Kempiak, J., Hollywood, L., Bolan, P., \& McMahon-Beattie, U. (2017). The heritage tourist: An understanding of the visitor experience at heritage attractions. International Journal of Heritage Studies, 23(4), 375-392.

Keul, A., \& Kühberger, A. (1997). Tracking the Salzburg tourist. Annals of Tourism Research, 24(4), 1008-1012.

Khairi, N. D. M., \& Ismail, H. N. (2015). Acknowledging the tourist spatial behavior for space management in urban heritage destination. International Journal of Built Environment and Sustainability, 2(4), 317-323.

Kim, H., Cheng, C. K., \& O’Leary, J. T. (2007). Understanding participation patterns and trends in tourism cultural attractions. Tourism Management, 28(5), 1366-1371.

Krakover, S. (2002). Time dimensions and tourism development in peripheral areas. In 
Krakover, S., \& Gradus, Y. (Eds.), Tourism in frontier areas (pp. 21-37). Lanham: Lexington Books.

Lau, W. G. (2007). Mapping tourist movement patterns: A GIS approach. The Hong Kong Polytechnic University, Kowloon, Hong Kong.

Lau, W. G., \& McKercher, B. (2006). Understanding tourist movement patterns in a destination: A GIS approach. Tourism and Hospitality Research, 7(1), 39-49.

Leiper, N. (1990). Tourist attraction systems. Annals of Tourism Research, 17(3), 367384.

Lew, A. A., \& McKercher, B. (2006). Modeling tourist movements: A local destination analysis. Annals of Tourism Research, 33(2), 403-423.

Li, N. (2019). Mainland Chinese cruise passengers' onshore experience. Tourism Recreation Research, 44(2), 217-231.

Li, Y., Yang, L., Shen, H., \& Wu, Z. (2019). Modeling intra-destination travel behavior of tourists through spatio-temporal analysis. Journal of Destination Marketing and Management, 11(November 2017), 260-269.

Lu, J., Hung, K., Wang, L., Schuett, M. A., \& Hu, L. (2016). Do perceptions of time affect outbound-travel motivations and intention? An investigation among Chinese seniors. Tourism Management, 53, 1-12.

Lue, C.C., Crompton, J. L., \& Fesenmaier, D. R. (1993). Conceptualization of multidestination pleasure trips. Annals of Tourism Research, 20(2), 289-301.

Lynch, K. (1960). The image of the city. Massachusetts: M.I.T Press.

Martin, B., \& Mason, S. (1993). The future for attractions: Meeting the needs of the 
new consumers. Tourism Management, 14(1), 34-40.

Martinez-Garcia, E., Raya-Vilchez, J. M., \& Galí-Espelt, N. (2018). Factors affecting time spent visiting heritage city areas. Sustainability, 10(6), 1-15.

McKean, J. R., Johnson, D. M., \& Walsh, R. G. (1995). Valuing time in travel cost demand analysis: An empirical investigation. Land Economics, 96-105.

McKercher, B., \& Lau, W.C. G. (2008). Movement patterns of tourists within a destination. Tourism Geographies, 10(3), 355-374.

McKercher, B., \& Lew, A. A. (2004). Tourist flows and the spatial distribution of tourists. In Lew, A. A., Hall, C. M., \& Williams, A. M. (Eds.), A Companion to Tourism (pp. 36-48). Malden: Blackwell.

MedCruise. (2019). Cruise activities in MedCruise ports STATISTICS 2018. Santa Cruz de Tenerife. Retrieved 22.03.20. from: www.medcruise.com

Ministerio de Fomento. (2019). Puertos del Estado. Retrieved 31.10.19. from: http://www.puertos.es/es-es/estadisticas/Paginas/estadistica_mensual.aspx

Muñoz-Mazón, A., Fuentes-Moraleda, L., Chantre-Astaiza, A., \& Burbano-Fernandez, M.-F. (2019). The study of tourist movements in tourist historic cities: A comparative analysis of the applicability of four different tools. Sustainability, 11(19), 52-65.

Navarro-Ruiz, S., Casado-Díaz, A. B., \& Ivars-Baidal, J. (2019). Cruise tourism: The role of shore excursions in the overcrowding of cities. International Journal of Tourism Cities, 6(1), 197-214.

Navarro-Ruiz, S., \& McKercher, B. (2020). The usability of visitor attractions: State-ofthe-art. Tourism Review, 75(3), 497-509. 
Oppermann, M. (1995). A model of travel itineraries. Journal of Travel Research, 33 (4), 57-61.

Paananen, K., \& Minoia, P. (2018). Cruisers in the city of Helsinki: Staging the mobility of cruise passengers. Tourism Geographies, 21(5), 801-821.

Packer, J., \& Ballantyne, R. (2016). Conceptualizing the visitor experience: A review of literature and development of a multifaceted model. Visitor Studies, 19(2), 128143.

Pearce, D. G. (1988). Tourist time-budget. Annals of Tourism Research, 15(1), 106121.

Perkins, H. C., \& Thorns, D. C. (2001). Gazing or performing? Introduction: The tourist performance. International Sociology, 16(2), 185-204.

Peypoch, N., \& Solonandrasana, B. (2007). On "E-Attraction" tourism destination Extension and application. Advances in Modern Tourism Research, 293-306.

Pine, B. J., \& Gilmore, J. H. (1998). Welcome to the experience economy. Harvard Business Review, 76(4), 97-105.

Pizam, A., \& Fleischer, A. (2005). The relationship between cultural characteristics and preference for active vs. passive tourist activities. Journal of Hospitality \& Leisure Marketing, 12(4), 5-25.

Puche-Ruiz, M., \& Obiol-Menero, E. M. (2011). Procesos de "re-imageneering" turístico: El eclipse de la identidad local de Valencia. Cuadernos de Turismo, 28, $191-214$.

Ram, Y., \& Hall, C. M. (2018). Walk score and tourist accommodation. International Journal of Tourism Cities, 4(3), 369-375. 
Rausell-Köster, P., Pardo-García, C., Coll-Serrano, V., \& Bustamante-Yábar, D. P. (2016). Cultural dimension and tourist satisfaction: The case of Valencia (Spain). Some notes for European urban tourism. In 19th International Conference on Cultural Economics2. Valladolid: Association for Cultural Economics International.

Renaud, L (2020). Reconsidering global mobility - distancing from mass cruise tourism in the aftermath of COVID-19. Tourism Geographies, 22 (3), 1-33

Salom-Carrasco, J., \& Pitarch-Garrido, M.-D. (2017). Análisis del impacto en el turismo de la estrategia de desarrollo urbano basada en megaproyectos: El caso de la ciudad de Valencia. Cuadernos de Turismo, 40, 573-598.

Sanz-Blas, S., Buzova, D., \& Carvajal-Trujillo, E. (2019). Familiarity and visit characteristics as determinants of tourists' experience at a cruise destination. Tourism Management Perspectives, 30(July 2018), 1-10.

Seraphin, H., Sheeran, P., \& Pilato, M. (2018). Over-tourism and the fall of Venice as a destination. Journal of Destination Marketing and Management, 9, 374-376.

Shoval, N. (2008). Tracking technologies and urban analysis. Cities, 25(1), 21-28.

Shoval, N., \& Isaacson, M. (2007). Tracking tourists in the digital age. Annals of Tourism Research, 34(1), 141-159.

Shoval, N., \& Isaacson, M. (2010). Tourist mobility and advanced tracking technologies. New York, NY: Routledge.

Taheri, B., Hosany, S., \& Altinay, L. (2019). Consumer engagement in the tourism industry: New trends and implications for research. Service Industries Journal, 39(7-8), 463-468. 
Taheri, B., Jafari, A., \& Gorman, K. O. (2014). Keeping your audience: Presenting a visitor engagement scale. Tourism Management, 42, 321-329.

Tashakkori, A., \& Teddlie, C. (2003). Handbook of mixed methods in social \& behavioral research. Thousand Oaks: Sage.

Thyne, M., Henry, J., \& Lloyd, N. (2015). Land ahoy: How cruise passengers decide on their shore experience. Tourism in Marine Environments, 10(3-4), 177-187.

Tideswell, C., \& Faulkner, B. (1999). Multidestination travel patterns of international visitors to Queensland. Journal of Travel Research, 37(May 1999), 364-374.

Trancoso González, A. (2018). Venice: The problem of overtourism and the impact of cruises. Investigaciones Regionales, 2018(42), 35-51.

Truong, T. P., \& Hensher, D. A. (1985). Measurement of travel time values and opportunity cost from a discrete-choice model author. The Economic Journal, 95(378), 438-451.

Turismo Valencia (2011). Plan Estratégico Turismo 2012-2015 y Plan de Actuaciones 2012. Valencia.

Turismo Valencia (2017). València Turística, hacia 2020. Valencia.

Urry, J. (1990). Tourist Gaze. London: Sage.

Urry, J., \& Larsen, J. (2011). The tourist gaze 3.0. London: Sage.

van der Knaap, W. G. M. (1997). GIS oriented methods for analysing tourist recreation complexes. Landbouwuniversiteit Wageningen (Wageningen Agricultural University).

Veal, A. J. (2006). Research methods for leisure and tourism: A practical guide (3rd 
ed.). Harlow: Pearson Education.

Voase, R. (2002). Rediscovering the imagination: Investigating active and passive visitor experience in the 21st century. International Journal of Tourism Research, 4(5), 391-399.

Walmsley, D. J., \& Jenkins, J. M. (1991). Mental maps, locus of control, and activity: A study of business tourists in coffs harbour. The Journal of Tourism Studies, 2(2), $36-42$.

Walsh, R. G., Sanders, L. D., \& McKean, J. R. (1990). The consumptive value of travel time on recreation trips. Journal of Travel Research, 21(1), 17-24.

Whyte, L. J., Packer, J., \& Ballantyne, R. (2018). Cruise destination attributes: Measuring the relative importance of the onboard and onshore aspects of cruising. Tourism Recreation Research, 43(4), 470-482.

Xia, J. C., Evans, F. H., Spilsbury, K., Ciesielski, V., Arrowsmith, C., \& Wright, G. (2010). Market segments based on the dominant movement patterns of tourists. Tourism Management, 31(4), 464-469.

Xu, D., Cong, L., \& Wall, G. (2019). Tourists' spatio-temporal behaviour and concerns in park tourism: Giant Panda National Park, Sichuan, China. Asia Pacific Journal of Tourism Research, 24(9), 924-943.

Zhang, H., Zhang, J., \& Kuwano, M. (2012). An integrated model of tourists' time use and expenditure behaviour with self-selection based on a fully nested Archimedean copula function. Tourism Management, 33(6), 1562-1573.

Zhao, S., Nyaupane, G. P., \& Andereckt, T. K. (2015). Exploring the differences between educational and escapist experience stagers: A multiperspective approach. 
Tourism Review International, 19(1987), 105-122.

Zillinger, M. (2007). Tourist routes: A time-geographical approach on German cartourists in Sweden. Tourism Geographies, 9(1), 64-83.

Zoltan, J., \& McKercher, B. (2015). Analysing intra-destination movements and activity participation of tourists through destination card consumption. Tourism Geographies, 17(1), 19-35. 
Table 1. Cruise visitors' intradestination behavior patterns

\begin{tabular}{|c|c|c|c|c|}
\hline Code & Pictogram & Description & Freq. & $\%$ \\
\hline \multicolumn{3}{|c|}{ Single-node visit } & 265 & $52.5 \%$ \\
\hline SNAV & $\backsim \bigcirc$ & $\begin{array}{l}\text { Movement to a single node where visitors } \\
\text { actively visited one or multiple attractions }\end{array}$ & 42 & $8.3 \%$ \\
\hline SNGS & & $\begin{array}{l}\text { Movement to a single node where visitors } \\
\text { passively visited the node (on foot or by bus; } \\
\text { panoramic) }\end{array}$ & 163 & $32.3 \%$ \\
\hline SNCM & & $\begin{array}{l}\text { Movement to a single node where visitors } \\
\text { combined active and passive participation } \\
\text { patterns }\end{array}$ & 60 & $11.9 \%$ \\
\hline \multicolumn{3}{|c|}{ Multiple-node visit } & 238 & $47.5 \%$ \\
\hline MNGS & & $\begin{array}{l}\text { Movement to multiple nodes, where visitors } \\
\text { performed passive participation patterns in } \\
\text { both. }\end{array}$ & 77 & $15.2 \%$ \\
\hline MNCM & & $\begin{array}{l}\text { Movement to multiple nodes, where visitors } \\
\text { combined active and passive participation } \\
\text { patterns }\end{array}$ & 161 & $32.2 \%$ \\
\hline \multicolumn{3}{|l|}{ Total } & 503 & $100 \%$ \\
\hline
\end{tabular}

Source: Authors 
Table 2. Summary of participant characteristics derived from questionnaires according to homogenous intradestination behaviour

\begin{tabular}{|c|c|c|c|c|c|c|c|}
\hline Variables & Categories & $\begin{array}{l}\begin{array}{l}\text { SNAV* } \\
(\mathrm{n}=42) \\
(\%)\end{array} \\
\end{array}$ & $\begin{array}{l}\text { SNGS* } \\
(\mathrm{n}=163) \\
(\%)\end{array}$ & $\begin{array}{l}\mathrm{SNCM}^{*} \\
(\mathrm{n}=66) \\
(\%)\end{array}$ & $\begin{array}{l}\begin{array}{l}\text { MNGS* } \\
(\mathrm{n}=77) \\
(\%)\end{array}\end{array}$ & $\begin{array}{l}\text { MNCM } \\
*(\mathrm{n}=161) \\
(\%)\end{array}$ & $\begin{array}{l}\text { p.value } \\
\text { of } x^{2} \\
\text { test }\end{array}$ \\
\hline Sex & $\begin{array}{l}\text { Male } \\
\text { Female }\end{array}$ & $\begin{array}{l}47.6 \\
52.4\end{array}$ & $\begin{array}{l}29 \\
71\end{array}$ & $\begin{array}{l}36.7 \\
63.3\end{array}$ & $\begin{array}{l}42.9 \\
57.1\end{array}$ & $\begin{array}{l}37.2 \\
62.8\end{array}$ & 0.083 \\
\hline Age & $\begin{array}{l}18-25 \\
26-35 \\
36-45 \\
46-55 \\
56-65 \\
66 \text { or more }\end{array}$ & $\begin{array}{l}6.0 \\
11.9 \\
16.8 \\
22.2 \\
26.5 \\
16.6\end{array}$ & $\begin{array}{l}3.1 \\
4.9 \\
9.2 \\
25.2 \\
26.7 \\
30.9\end{array}$ & $\begin{array}{l}\cdot \\
6.3 \\
12.7 \\
8.8 \\
37.3 \\
35.0\end{array}$ & $\begin{array}{l}1.6 \\
11.4 \\
26.2 \\
20.0 \\
20.2 \\
20.5\end{array}$ & $\begin{array}{l}.7 \\
6.9 \\
13.8 \\
19.3 \\
29.4 \\
29.9\end{array}$ & 0.013 \\
\hline Employment & $\begin{array}{l}\text { Employee } \\
\text { Retired } \\
\text { Others } \\
\text { (unemployed, } \\
\text { student, housework } \\
\text { \& others) }\end{array}$ & $\begin{array}{l}43.7 \\
38.4 \\
17.9\end{array}$ & $\begin{array}{l}52 \\
40.9 \\
7.1\end{array}$ & $\begin{array}{l}46.5 \\
47.7 \\
5.9\end{array}$ & $\begin{array}{l}67.1 \\
21.5 \\
11.5\end{array}$ & $\begin{array}{l}56.9 \\
35.6 \\
6.7\end{array}$ & 0.065 \\
\hline $\begin{array}{l}\text { Monthly net } \\
\text { household } \\
\text { income }\end{array}$ & $\begin{array}{l}\text { Less than } € 1.000 \\
€ 1.000-€ 2.000 \\
€ 2.001-€ 3.000 \\
€ 3.001-€ 4.000 \\
\text { More than } € 4.000 \\
\text { No answer }\end{array}$ & $\begin{array}{l} \\
7.4 \\
16.6 \\
25.2 \\
32.9 \\
18\end{array}$ & $\begin{array}{l}2.0 \\
19.1 \\
11.7 \\
14.2 \\
34.5 \\
18.5\end{array}$ & \begin{tabular}{l|l|} 
& \\
13.9 & \\
15.9 & \\
14.5 & \\
34.9 \\
20.8
\end{tabular} & $\begin{array}{l}\cdot \\
4.9 \\
13.2 \\
13.0 \\
34.0 \\
34.9\end{array}$ & $\begin{array}{l}2.0 \\
11.1 \\
13.7 \\
16.7 \\
32.7 \\
23.8\end{array}$ & 0.202 \\
\hline Residence & $\begin{array}{l}\text { Europe } \\
\text { North America } \\
\text { Latin America } \\
\text { Asia-Pacific }\end{array}$ & $\begin{array}{l}95.6 \\
4.4 \\
. \\
.\end{array}$ & $\begin{array}{l}82.4 \\
11.5 \\
3.7 \\
2.4\end{array}$ & $\begin{array}{l}73.8 \\
17.8 \\
2.1 \\
6.3\end{array}$ & $\begin{array}{l}73.9 \\
11.3 \\
3.3 \\
8\end{array}$ & $\begin{array}{l}70 \\
18.5 \\
2.3 \\
9.1\end{array}$ & 0.030 \\
\hline Party size & $\begin{array}{l}\text { Alone } \\
\text { Couple/Partner }\end{array}$ & $\begin{array}{l}4.6 \\
48.6\end{array}$ & $\begin{array}{l}1.1 \\
58.2\end{array}$ & $\begin{array}{l}3.5 \\
67.5\end{array}$ & $\begin{array}{l}3.6 \\
48.5\end{array}$ & $\begin{array}{l}2.2 \\
63.8\end{array}$ & 0.294 \\
\hline
\end{tabular}




\begin{tabular}{|c|c|c|c|c|c|c|c|}
\hline & $\begin{array}{l}\text { Friends } \\
\text { Family } \\
\text { Family \& friends }\end{array}$ & $\begin{array}{l}5.9 \\
37.9 \\
3\end{array}$ & $\begin{array}{l}10.6 \\
24.3 \\
5.8\end{array}$ & $\begin{array}{l}5.9 \\
20.5 \\
2.6\end{array}$ & $\begin{array}{l}8.2 \\
29.8 \\
9.9\end{array}$ & $\begin{array}{l}5.6 \\
23.4 \\
4.9\end{array}$ & \\
\hline $\begin{array}{l}\text { Familiarity } \\
\text { Valencia }\end{array}$ & $\begin{array}{l}\text { First timer } \\
\text { Repeater }\end{array}$ & $\begin{array}{l}75 \\
25\end{array}$ & $\begin{array}{l}73.4 \\
26.6\end{array}$ & $\begin{array}{l}68.3 \\
31.7\end{array}$ & $\begin{array}{l}86.6 \\
13.4\end{array}$ & $\begin{array}{l}80.5 \\
19.5\end{array}$ & 0.057 \\
\hline $\begin{array}{l}\text { Onshore } \\
\text { visit choice }\end{array}$ & $\begin{array}{l}\text { Independent } \\
\text { Guided }\end{array}$ & $\begin{array}{l}80.5 \\
19.5\end{array}$ & $\begin{array}{l}92 \\
8\end{array}$ & $\begin{array}{l}70.3 \\
29.7\end{array}$ & $\begin{array}{l}93.6 \\
6.4\end{array}$ & $\begin{array}{l}39.7 \\
60.3\end{array}$ & 0.000 \\
\hline $\begin{array}{l}\text { Information } \\
\text { search }\end{array}$ & $\begin{array}{l}\text { Yes } \\
\text { No }\end{array}$ & $\begin{array}{l}85 \\
15\end{array}$ & $\begin{array}{l}79 \\
21\end{array}$ & $\begin{array}{l}72.7 \\
27.8\end{array}$ & $\begin{array}{l}83.6 \\
16.4\end{array}$ & $\begin{array}{l}80.1 \\
19.9\end{array}$ & 0.412 \\
\hline $\begin{array}{l}\text { Attraction's } \\
\text { interest }\end{array}$ & $\begin{array}{l}\text { Special interest } \\
\text { General interest }\end{array}$ & $\begin{array}{l}85.3 \\
14.7\end{array}$ & $\begin{array}{l}44 \\
56\end{array}$ & $\begin{array}{l}57.2 \\
42.8\end{array}$ & $\begin{array}{l}52 \\
48\end{array}$ & $\begin{array}{l}61.7 \\
38.3\end{array}$ & 0.000 \\
\hline $\begin{array}{l}\text { Itinerary } \\
\text { intention }\end{array}$ & $\begin{array}{l}\text { Itinerary planned } \\
\text { Wander around }\end{array}$ & $\begin{array}{l}75.8 \\
21.2\end{array}$ & $\begin{array}{l}12.3 \\
84.6\end{array}$ & $\begin{array}{l}42.3 \\
57.7\end{array}$ & $\begin{array}{l}35 \\
55\end{array}$ & $\begin{array}{l}74 \\
21.5\end{array}$ & 0.000 \\
\hline $\begin{array}{l}\text { Time } \\
\text { schedule }\end{array}$ & $\begin{array}{l}\text { Yes } \\
\text { No }\end{array}$ & $\begin{array}{l}83.6 \\
16.4\end{array}$ & $\begin{array}{l}38.5 \\
61.5\end{array}$ & $\begin{array}{l}73.8 \\
26.2\end{array}$ & $\begin{array}{l}45 \\
55\end{array}$ & $\begin{array}{l}82 \\
18\end{array}$ & 0.000 \\
\hline $\begin{array}{l}\text { Attractions } \\
\text { visited }\end{array}$ & $\begin{array}{l}\text { Visit a lot } \\
\text { Visit a few } \\
\text { intensely }\end{array}$ & $\begin{array}{l}16.4 \\
83.6\end{array}$ & $\begin{array}{l}50.2 \\
47.5\end{array}$ & $\begin{array}{l}49.7 \\
42.8\end{array}$ & $\begin{array}{l}55.6 \\
36.5\end{array}$ & $\begin{array}{l}53.3 \\
38.5\end{array}$ & 0.000 \\
\hline $\begin{array}{l}\text { Length of } \\
\text { visit }\end{array}$ & Average & $\begin{array}{l}4 \mathrm{~h} \\
40 \mathrm{~min}\end{array}$ & $4 \mathrm{~h}$ & $\begin{array}{l}4 \mathrm{~h} \\
40 \min \end{array}$ & $5 \mathrm{~h} \mathrm{30min}$ & 5hours & 0.000 \\
\hline & Max. & $\begin{array}{l}6 \mathrm{~h} \\
35 \mathrm{~min}\end{array}$ & $9 \mathrm{~h}$ & $9 \mathrm{~h}$ & $8 \mathrm{~h}$ & $8 \mathrm{~h}$ & \\
\hline & Min. & $\begin{array}{l}3 \mathrm{~h} \\
20 \min \end{array}$ & $50 \mathrm{~min}$ & $\begin{array}{l}2 \mathrm{~h} \\
50 \mathrm{~min}\end{array}$ & $3 \mathrm{~h} 25 \mathrm{~min}$ & $3 \mathrm{~h} 30 \mathrm{~min}$ & \\
\hline \multicolumn{2}{|c|}{ Satisfaction** } & 6.40 & 6.42 & 6.48 & 6.34 & 6.67 & 0.069 \\
\hline \multicolumn{2}{|c|}{ Recommendation** } & 6.28 & 6.40 & 6.59 & 6.44 & 6.64 & 0.219 \\
\hline \multicolumn{2}{|c|}{ Intention to return** } & 4.97 & 4.87 & 4.96 & 5.15 & 5.02 & 0.091 \\
\hline
\end{tabular}

* Intradestination behaviour pattern codes explained in Table 1

** Average (Likert scale 1-7).

Source: Authors 
Figure 1. Methodological framework of the study.

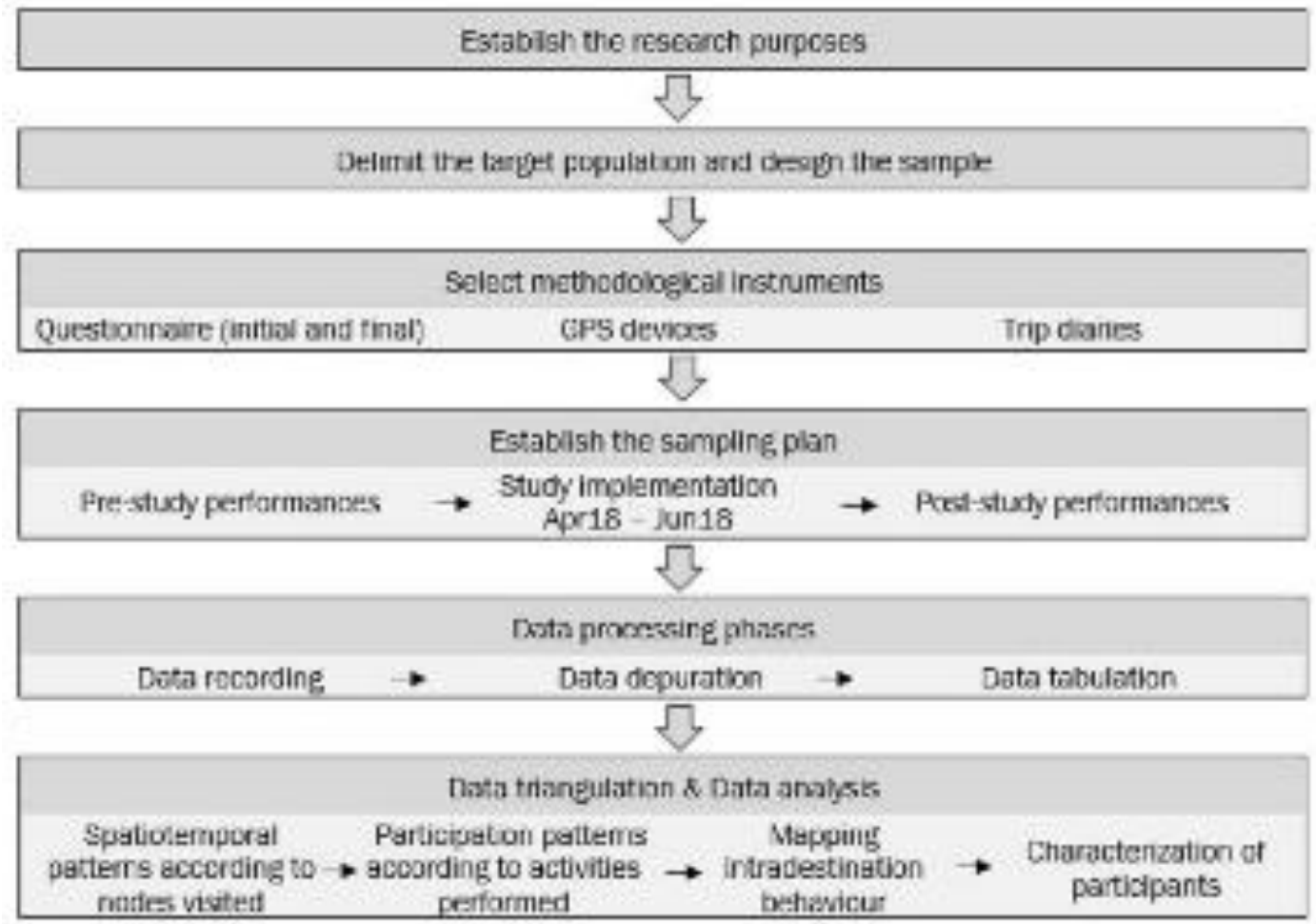

Figure 2. Valencia and its tourist nodes
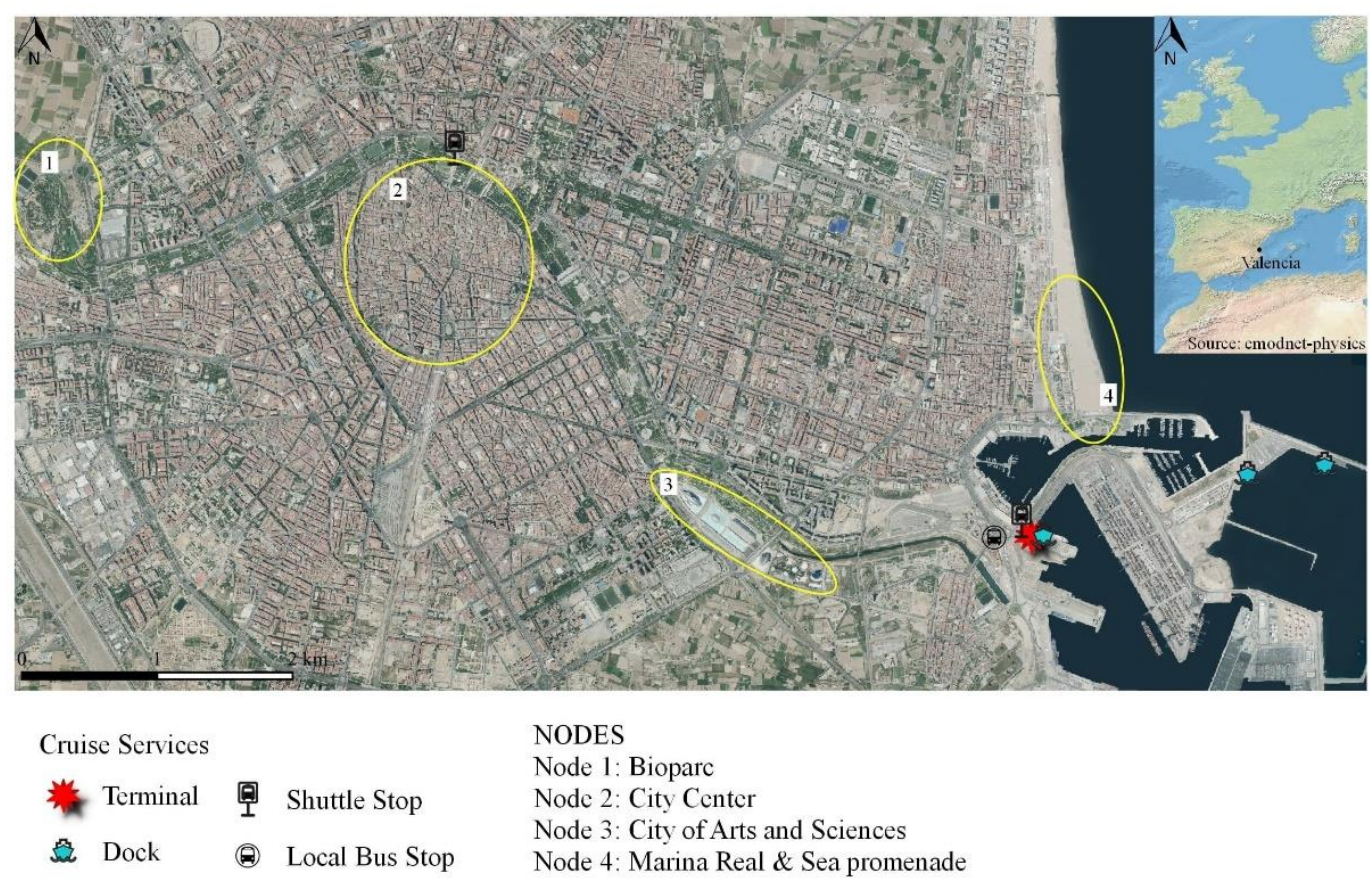

NODES

Node 1: Bioparc

Node 2: City Center

Node 3: City of Arts and Sciences

Node 4: Marina Real \& Sea promenade 
Figure 3. Movement to a single node and active participation pattern

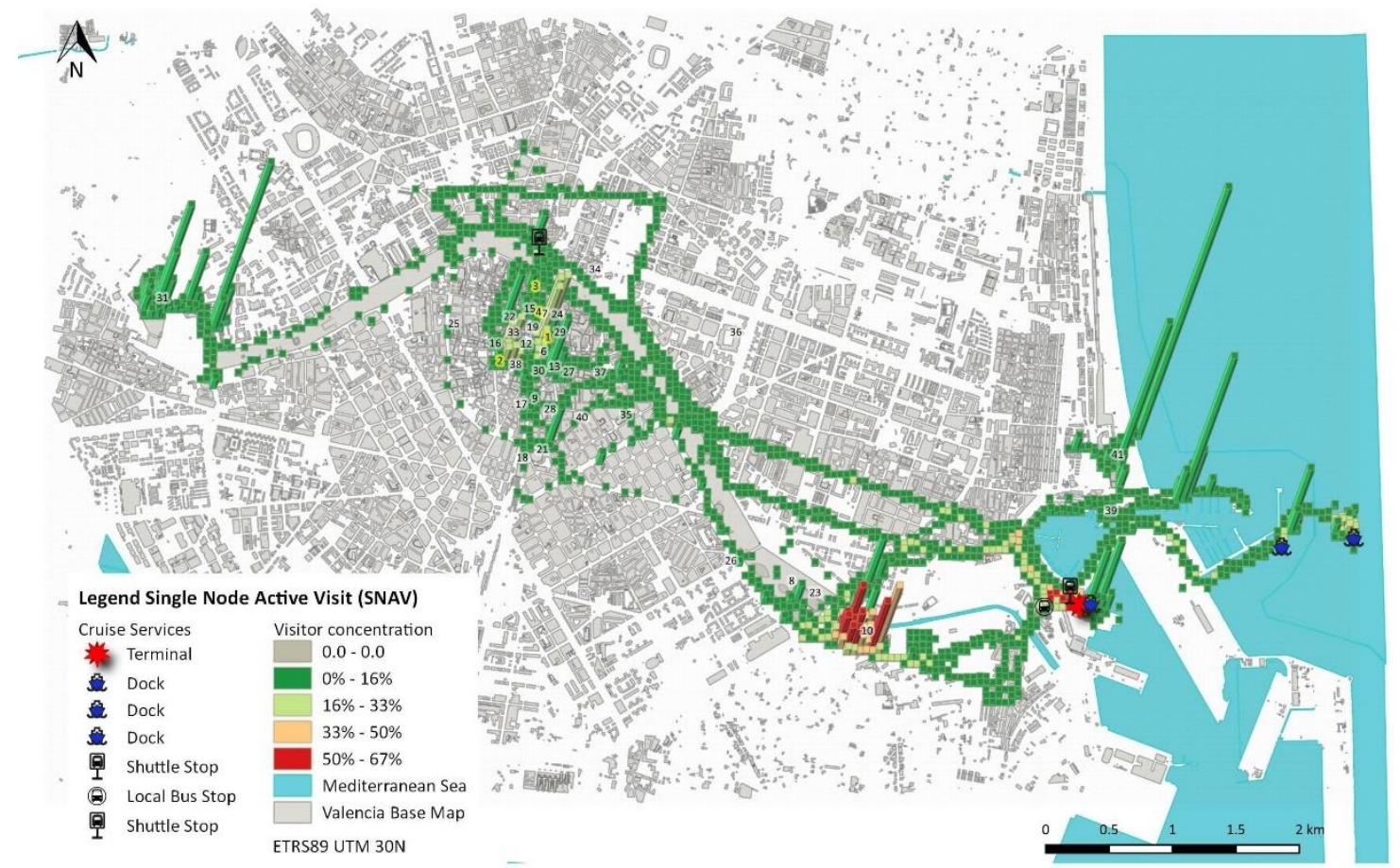

Figure 4. Movement to a single node and passive participation pattern

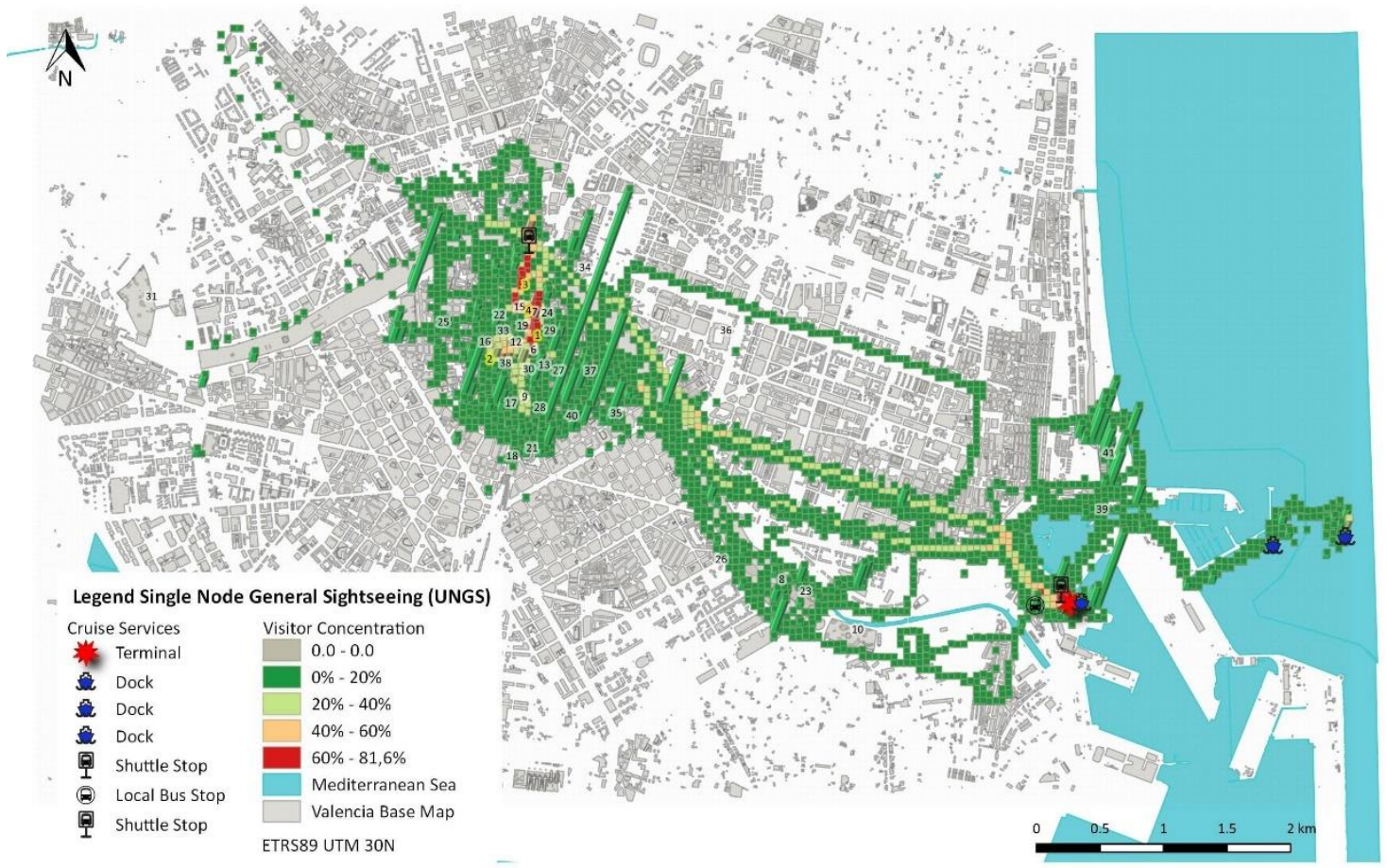


Figure 5. Movement to a single node and combination of active and passive

participation pattern

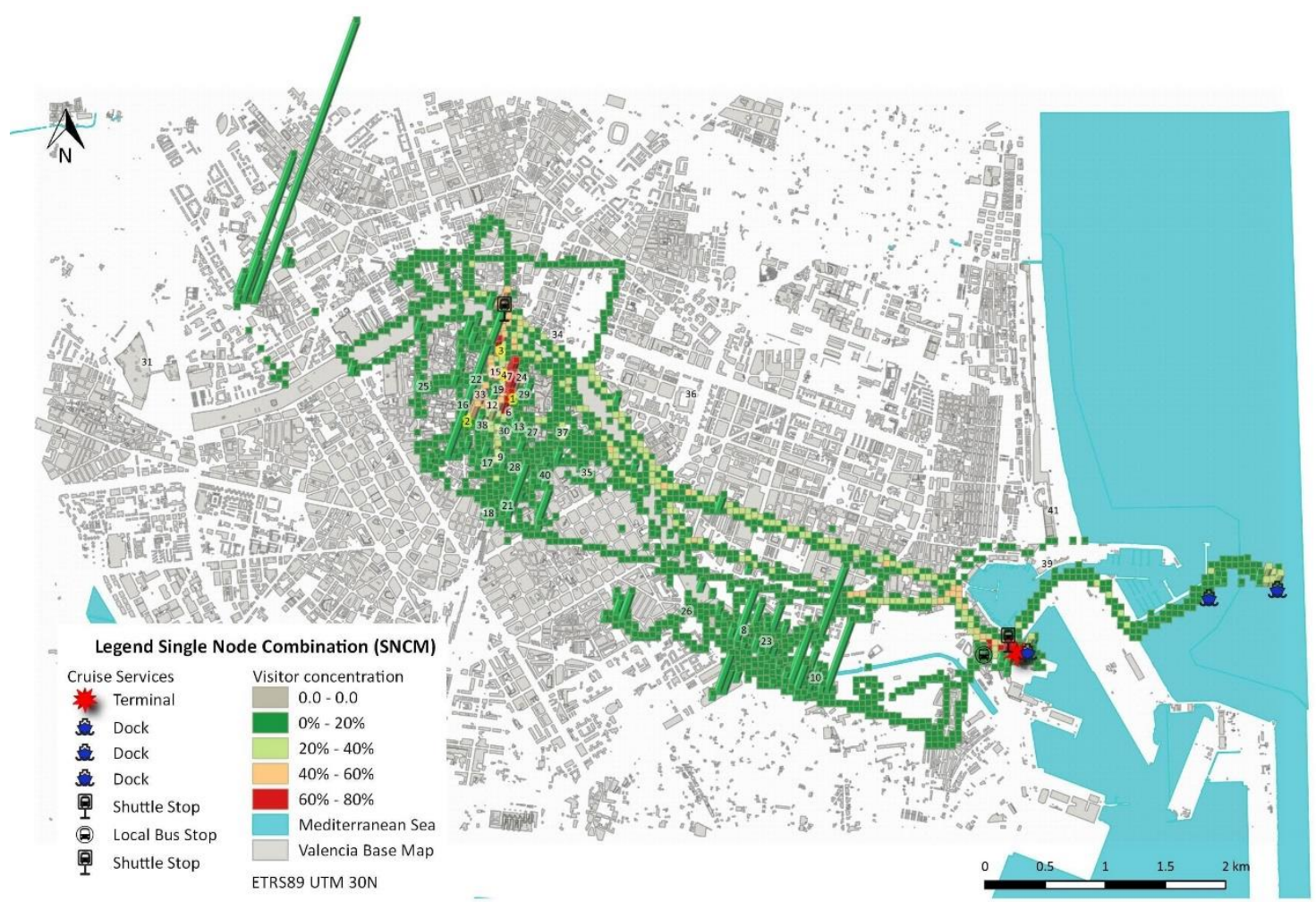

Figure 6. Movement to multiple nodes and passive participation pattern

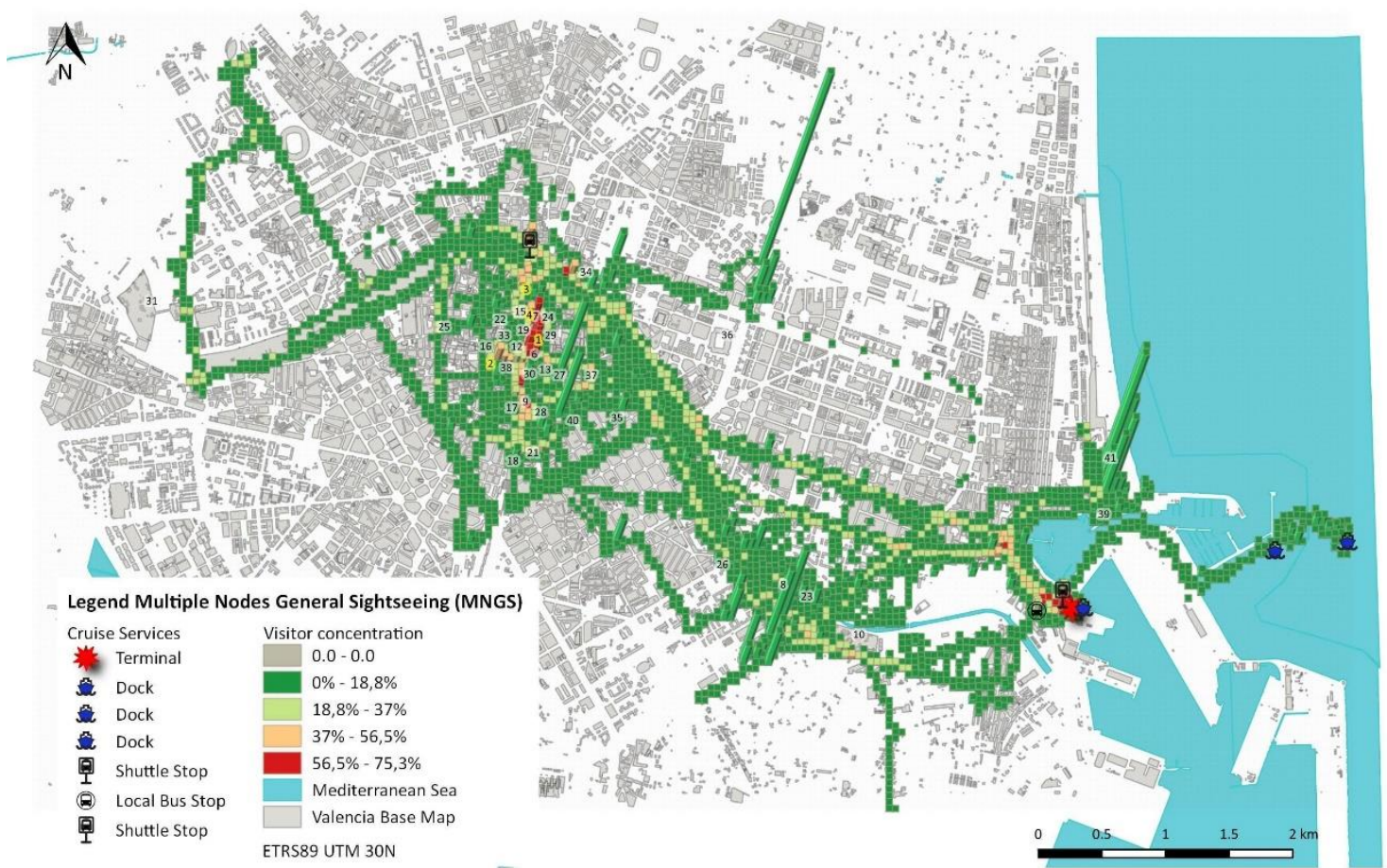


Figure 7. Movement to multiple nodes and combination of active and passive

\section{participation pattern}

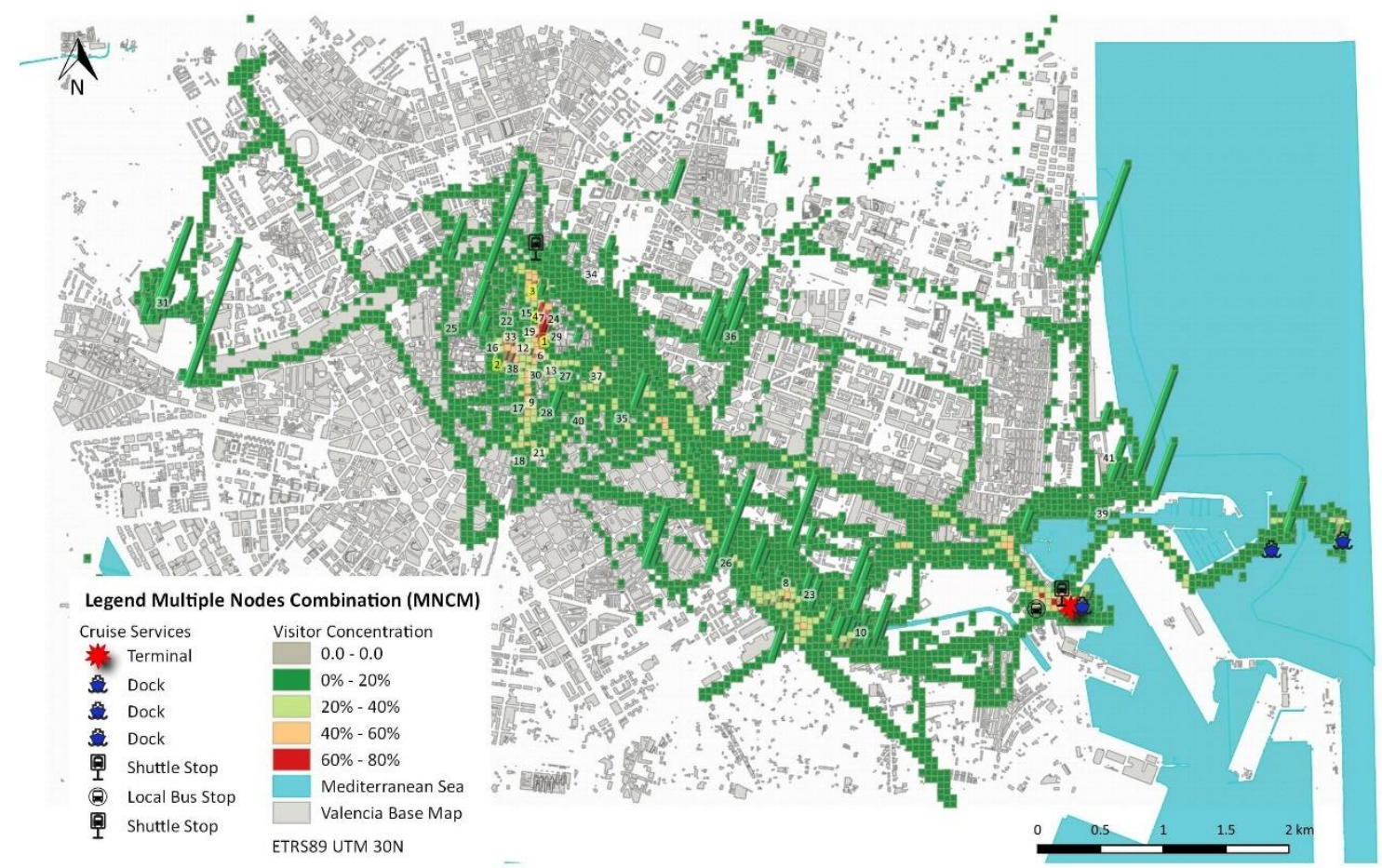

Figure 8. Visitor Attraction list

\begin{tabular}{|c|c|c|c|c|c|c|c|c|c|c|c|c|c|c|c|c|c|c|c|}
\hline 1 & Catedral & 5 & $\begin{array}{l}\text { Lonja de la } \\
\text { Seda }\end{array}$ & 9 & $\begin{array}{l}\text { Plaza } \\
\text { Ayuntamiento }\end{array}$ & 13 & $\begin{array}{l}\text { Palau } \\
\text { Marques de } \\
\text { Dos Aguas }\end{array}$ & 17 & Ayuntamiento & 21 & $\begin{array}{l}\text { Plaza de } \\
\text { Toros }\end{array}$ & 25 & $\begin{array}{l}\text { Torres de } \\
\text { Quart }\end{array}$ & 29 & $\begin{array}{l}\text { Cripta San } \\
\text { Vicente }\end{array}$ & 33 & $\begin{array}{l}\text { Iglesia Sag. } \\
\text { Corazón }\end{array}$ & 3 & Parterre \\
\hline 2 & $\begin{array}{l}\text { Mercado } \\
\text { Central }\end{array}$ & 6 & $\begin{array}{l}\begin{array}{l}\text { Plaza de la } \\
\text { Reina }\end{array} \\
\end{array}$ & 10 & Oceanográfico & 14 & $\begin{array}{l}\text { Iglesia Santa } \\
\text { Catalina }\end{array}$ & 18 & $\begin{array}{l}\text { Estación del } \\
\text { Norte }\end{array}$ & 22 & \begin{tabular}{|l|}
$\begin{array}{l}\text { Iglesia San } \\
\text { Nicolás }\end{array}$ \\
\end{tabular} & 26 & \begin{tabular}{|l|} 
Museo \\
Fallero \\
\end{tabular} & 30 & \begin{tabular}{|l|} 
Iglesia de \\
San Martin \\
\end{tabular} & 34 & \begin{tabular}{|l} 
Museo de \\
Bellas Artes
\end{tabular} & 38 & $\begin{array}{l}\text { Plaza del } \\
\text { Mercado }\end{array}$ \\
\hline 3 & $\begin{array}{l}\text { Torres de } \\
\text { Serrano }\end{array}$ & 7 & $\begin{array}{l}\text { Basilica de los } \\
\text { Desamparados }\end{array}$ & 11 & $\begin{array}{l}\text { Plaza } \\
\text { Redonda }\end{array}$ & 15 & $\begin{array}{l}\text { Palau } \\
\text { Generalitat }\end{array}$ & 19 & Miguelete & 23 & \begin{tabular}{|l} 
Museo \\
Ciencias \\
P.Felipe \\
\end{tabular} & 27 & $\begin{array}{l}\text { Plaza del } \\
\text { patriarca }\end{array}$ & 31 & Bioparc & 35 & $\begin{array}{l}\text { Mercado } \\
\text { Colon }\end{array}$ & 39 & $\begin{array}{l}\text { Veles e } \\
\text { Vents }\end{array}$ \\
\hline 4 & $\begin{array}{l}\text { Plaza de la } \\
\text { Virgen }\end{array}$ & 8 & $\begin{array}{l}\text { Ciudad Artes } \\
\text { y Ciencias }\end{array}$ & 12 & $\begin{array}{l}\text { Cauce del río } \\
\text { Turia }\end{array}$ & 16 & $\begin{array}{l}\text { Iglesia } \\
\text { Santos } \\
\text { Juanes }\end{array}$ & 20 & Horchatería & 24 & $\begin{array}{l}\text { Plaza } \\
\text { Almoina }\end{array}$ & 28 & $\begin{array}{l}\text { Edificio de } \\
\text { correos }\end{array}$ & 32 & \begin{tabular}{|l} 
Plaza del \\
Collado
\end{tabular} & 36 & $\begin{array}{l}\text { Estadio } \\
\text { fútbol } \\
\text { Mestalla }\end{array}$ & 40 & Calle Colon \\
\hline
\end{tabular}

